\title{
Age changes of musculoskeletal stress markers and their inter-period comparisons
}

\author{
Wataru TAKIGAWA ${ }^{1 *}$ \\ ${ }^{1}$ School of Health Sciences at Fukuoka, International University of Health and Welfare, Fukuoka 831-8501, Japan
}

Received 13 May 2013; accepted 7 December 2013

\begin{abstract}
This study examines the changes with age of 15 musculoskeletal stress markers (MSMs) in the upper and lower limb bones of modern Japanese with documented ages-at-death, on the basis of original scoring criteria corresponding to each advanced stage. The procedure investigated significant differences of mean scores among five age classes at intervals of 10 years from 20 to 69 years for each MSM, and also calculated Pearson's correlation coefficients between MSM scores and age-at-death. These examinations found that most MSMs had significant correlations with aging in both sexes. MSM data of the people from the Yoshigo shell-mound in the Jomon period (Yoshigo Jomon, c. 3000-2300 BP), the Doigahama site in the Yayoi period (Doigahama Yayoi, c. 2100-1800 BP), and modern Japanese were then compared between the 20-39 and 40-59 age categories (younger adult and older adult groups, respectively) for both sexes. Kruskal-Wallis tests found that many MSMs showed significant differences between periods in each age category. Mann-Whitney tests revealed that many MSMs of the prehistoric Yoshigo Jomon and Doigahama Yayoi showed few significant differences, whereas those of many modern Japanese differed significantly. Principal component analysis indicated that the results of a scatter diagram in the younger adult group were considerably different from those of the older adult group. These findings suggest that MSMs are age structured within human populations, but that differences also arise in association with intensity of activity.
\end{abstract}

Key words: musculoskeletal stress marker (MSM), age changes, modern Japanese, Jomon, Yayoi

\section{Introduction}

Musculoskeletal stress markers (MSMs) are osseous changes observed on the muscle attachment portions of bones, especially postcranial limb bones. Enthetic MSMs are divided into two types in terms of muscle attachment morphology: a fibrous type and a fibrocartilaginous type. In the former type, the collagenous tendon attaches directly to the bone, whereas the latter type displays four stages of histological zones in the transition from tendon to bone. Hawkey and Merbs (1995) classified these osseous changes into three categories, i.e. robusticity marker, stress lesion, and ossification exostosis. The robusticity marker is the normal reaction to habitual muscle usage and reflects daily activities that produce rugged markings at the muscle attachment. This marker is observed as a sharp ridge or crest. The stress lesion is defined as a pitting or furrow on the cortical bone. This pattern appears to be activity induced as a result of continual microtrauma at the attachment site. The ossification exostosis is usually due to an abrupt macrotrauma. When a bone avulsion injury occurs, new bone formation may be incorporated into the muscle tissue, and result in an exostosis. These

\footnotetext{
* Correspondence to: Wataru Takigawa, 1-5-11 Miyamoto, Funabashi City, Chiba Prefecture, 273-0003, Japan (present address).

E-mail: takigaww2004@yahoo.co.jp

Published online 6 March 2014

in J-STAGE (www.jstage.jst.go.jp) DOI: 10.1537/ase.131207
}

osseous changes are relatively prevalent in adults after the growth of the skeletal system has been fully completed, and are often considered to reflect physical activities based on daily subsistence or habits during the lifetime of the individual (Hawkey and Merbs, 1995; Chapman, 1997; Churchill and Morris, 1998; Peterson, 1998; Steen and Lane, 1998; al-Oumaoui et al., 2004; Eshed et al., 2004; Molnar, 2006, 2010; Weiss, 2007; Lieverse et al., 2009, 2013; Havelková et al., 2011; Schrader, 2012; Stefanović and Porčić, 2013).

Although Hawkey and Merbs' (1995) method is widely used for scoring MSMs studies, it has some problems. (i) Muscular and ligamentous markers are not distinguished. Muscles are different from ligaments in both embryological origin and anatomical function. Clavicular ligaments in particular cannot be discussed in the same way as muscles. (ii) Some minute changes of muscle attachment are difficult to score in actual materials by macroscopic observation (e.g. scapular markers). (iii) It is doubtful whether all muscles match the defined scores of robusticity marker, stress lesion, and ossification exostosis. Each muscle may need its own definition for proper scoring. (iv) Treatment of difficultto-score borderline MSMs are not clear (For example, how do researchers record an intermediate score between phase 1 and phase 2?). This method presents a risk of inter- or intraobserver error in respective scorings.

Many researchers have considered the relationships between MSMs and age. Chapman (1997) investigated the relationship between MSM intensity of upper limb bones and 
age category in Pecos Pueblo Native Americans, and found that there were statistically significant differences between young and middle-aged adults in some muscle/ligament insertion features. Wilczak (1998) compared the total area of seven muscle insertions of the humerus in individuals between 20 and 40 years of age based on the Terry/ Hamann-Todd collection (20th-century specimens with museum records of death certificates and autopsies). This study revealed that the total insertion area of the muscle was significant greater in 40 year old males than in 20 year old males. Robb (1998) compared MSM scores of the upper and lower limb bones between age categories in an archaeological sample from the Pontecagnano cemetery ( 7 th-3rd century BC) in southern Italy. He suggested that average MSM score exhibits curvilinear change as aging progresses.

Weiss $(2003,2004)$ investigated the total MSM scores in each of the upper limbs (7 insertion sites) and lower limbs (20 insertion sites) in the skeletal remains of Native British Columbians (3500-1500 BP) and prisoners in Quebec (18th century). The total MSM score correlated with age significantly in both the upper and lower limbs (correlation coefficients: $r=0.49$ in the upper limbs, $r=0.61$ in the lower limbs, $P<0.001$ in both). The research found that older individuals had higher scores and that age was the best overall predictor of MSMs. A similar report also came from the upper limb bone sample of prehistoric Native Americans from Central California (Weiss, 2007). Molnar (2006) and Molnar et al. (2011) studied frequencies of MSM scores in age-specific contexts among Middle Neolithic skeletons from Gotland Island. These studies showed that aging could account to a considerable degree for higher MSM scores.

Whereas the above studies suggest that aging affects MSM scores, most of these analyses were made on the basis of archaeological materials where the correct age-at-death was unknown. Wilczak (1998) used the Terry/Hamann-Todd collection, which is supplied with records of death certificates. However, the analyzed data was derived from only the humerus of a mixed sample of European and African origins. Biological and socioeconomic background is likely to be different between these populations.

Therefore, recent studies have tried to establish relationships between aging and MSM scores in modern skeletal collections with known ages-at-death. Cardoso and Henderson (2010) demonstrated that there was no association between activity and enthesopathies, and that age was the single most significant factor in enthesopathy formation in late-19th- to early-20th-century cemeteries in Portugal. Niinimäki (2011) concluded that age and muscle size were the most powerful factors to explain MSM scores in the upper limbs of early-20th-century Finns. Muscle attachment areas and MSMs exhibited increasing patterns with advanc- ing age. Milella et al. (2012) investigated postcranial entheses in a large contemporary Italian skeletal series and reported a strong relationship between aging and entheseal changes. Entheseal morphology primarily reflected age, and its association with lifetime activity patterns remained ambiguous.

The current study differs from similar previous attempts by tracking the correlation between age and MSMs, while also exploring differences in MSM expression between populations with different subsistence economies. The work endeavors to provide an enhanced understanding of the development of these features over the human lifespan and of how strain may differentially influence expression. Two hypotheses are tested to achieve this goal: (i) aging is a significant factor for MSM expression in modern Japanese; and (ii) there are significant differences between modern and prehistoric groups in MSM expression when aging is considered.

\section{Materials and Methods}

\section{Materials}

The modern skeletal materials in this study were anatomical cadaveric specimens of Japanese skeletons. These materials were all adults who lived in the later 19th to early 20th centuries (Table 1). Selected modern Japanese skeletons were identified as to their age-at-death on the basis of body donation records. The subjects were classified into five age classes (20-29, 30-39, 40-49, 50-59, and 60-69 years) and three age stages from 'younger adult' (20-39 years), 'older adult' (40-59 years), and 'senile adult' (60-69 years).

Archaeological skeletal materials were chosen on the basis of sample size (Figure 1, Table 1). For the Jomon period (settled hunter-gatherer society), the Yoshigo shellmound in Aichi prefecture (Yoshigo Jomon: c. 3000-2300 BP) has one of the largest number of individuals recovered from an archaeological site. For the Yayoi period (the first intensive farming society based on paddy rice), skeletons from the Doigahama site in Yamaguchi prefecture (Doigahama Yayoi: ca. $2100-1800$ BP) are the best preserved.

\section{Criteria for scoring MSM}

The skeletal elements used in this study are shown in Figure 2 and listed in Table 2. Free parts of the upper and lower limbs (humerus, radius, ulna, femur, patella, tibia, and calcaneus) were observed in this investigation. MSMs were selected based on the following standards: (i) traits originating from skeletal muscles but not ligaments (with the exception of the patellar ligament), (ii) insertions relative to main muscles in motion of the whole body and major joints such as shoulder, elbow, hip, knee, and ankle; (iii) easy to assess by macroscopic observation or palpation, and showing some

Table 1. Skeletal materials used in present study

\begin{tabular}{clccl}
\hline Period & \multicolumn{1}{c}{ Sites } & Male $(n)$ & Female $(n)$ & \multicolumn{1}{c}{ Collections } \\
\hline Jomon & Yoshigo shell mound & 96 & 115 & $\begin{array}{l}\text { Kyoto University Museum } \\
\text { Tahara Municipal Museum }\end{array}$ \\
Yayoi & $\begin{array}{l}\text { Doigahama site } \\
\text { Modern }\end{array}$ & 87 & 66 & $\begin{array}{l}\text { Kyushu University Museum } \\
\text { School of Medicine, Chiba University } \\
\text { Kyoto University Museum }\end{array}$ \\
\hline
\end{tabular}




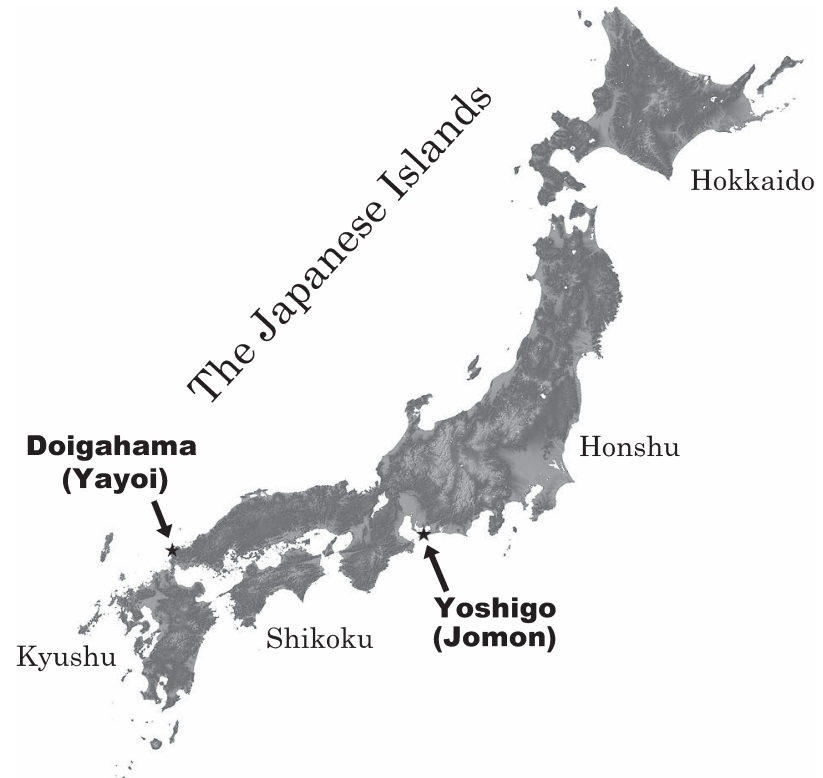

Figure 1. Geographical locations of the Jomon period Yoshigo shell-mound and the Yayoi period Doigahama site in the used in the present study.

degree of frequency among various populations.

Scoring of each MSM was performed in accordance with advanced stages. Scores were recorded on a scale from 0 to 3 , and the scoring criteria are explicitly described in Table 1 and Figure 2. In ambiguous cases, i.e. situations where scores fell between two qualitative values, intermediate scores were assigned (e.g. 1.5 for expressions that fall between 1 and 2).

\section{Comparisons among the Jomon, Yayoi, and modern Japanese}

MSM data sets of the Yoshigo Jomon, Doigahama Yayoi, and modern Japanese were divided into the younger adult and older adult groups. The age-at-death of archaeological skeletons was assessed based on cranial sutures, dental attrition, and pubic symphysis surfaces (Lovejoy, 1985; Buikstra and Ubelaker, 1994). Then, each age- and sex-separated group was treated as the further analytical unit. A KruskalWallis test was conducted to find inter-population differences among the Yoshigo Jomon, Doigahama Yayoi, and modern Japanese. Mann-Whitney tests were also carried out between age categories in each population.

Finally, principal component analyses (PCA) among the three groups were conducted in the younger adult and older adult groups, and the age-pooled sample. PCA was employed to further evaluate contributing factors to MSM formation, namely subsistence categories and age groups. Statistical procedures were performed by using SPSS 14.0 for Windows (SPSS Inc.).

\section{Results}

Age changes of MSMs in each age class

For the modern Japanese materials, MSM score data were mixed between right and left sides and divided into five age classes (20-29, 30-39, 40-49, 50-59, and 60-69 years). For each age class, the basic statistics of each MSM were calculated separately for males and females (Table 3, Figure 3).

Kruskal-Wallis tests among the five age classes confirmed significant age differences (Table 3, Figure 3). In the upper limbs, LTC, DT, RT and OL showed significant age changes in both sexes. In the lower limbs, all MSMs exhibited significant age differences. In many of the examined MSMs, the age class of 20-29 years had the lowest score (DT, RT, OL, GT, LT, LA, PB, SL, TT, and CT). While the highest score was observed in the age class of 50-59 years in many MSMs of males (DT, SC, GT, LT, GLT, LA, PB, TT, and CT), most MSM scores were highest in the age class of 60-69 years in females (GTC, LTC, DT, RT, OL, UT, GT, LT, GLT, LA, PB, TT, and CT). A linearly increasing pattern from the lowest to the highest age class was observed in MSMs around the elbow joint (RT: insertion in tendon of biceps brachii; OL: insertion in tendon of triceps brachii), in both males and females.

In 13 MSMs out of 15, Pearson's correlation coefficients between the MSM score and age were statistically significant (Table 4). MSMs that did not show significant correlation with age were GTC and SC in males, and UT and GLT in females. These are upper-limb MSMs. All lower-limb MSMs showed significant correlation.

\section{Comparisons among the Jomon, Yayoi, and modern Japanese}

Kruskal-Wallis tests revealed significant population differences of MSM expression among Yoshigo Jomon, Doigahama Yayoi, and modern Japanese (Figure 4 and Table 5). In younger adult males, 9 MSMs differed significantly as did 11 MSMs in older adult males. Among those MSMs, seven (GTC, DT, SC, UT, LT, GLT, and PB) were common between two age groups. Eleven MSMs differed significantly in younger adult females, and in 10 in older adult females. Among those MSMs, seven (GTC, LTC, DT, RT, SC, GT, and CT) were common.

Averaged scores of 15 MSMs are also given in Table 5. Except for older adult males, the score was highest in Yoshigo Jomon. In older adult males, the highest score was observed in modern Japanese.

A Mann-Whitney test was performed to reveal inter-age group difference (Table 6). In Yoshigo Jomon and Doigahama Yayoi, most MSMs did not show significant differences. In contrast, many of the MSMs showed a significant difference between the younger and older adult groups in modern Japanese (in both sexes).

In the scatter diagrams of PCA (Figure 5), the younger adult, older adult, and mixed age group showed different patterns. However, the older adult group showed results that resembled that of the mixed age group.

\section{Discussion}

\section{Age changes of MSMs in modern Japanese}

In the investigation of modern Japanese, the present study confirmed significant correlations between most MSM scores and age-at-death. Many MSM traits develop in 
(a)

$\begin{array}{llll}\text { Phase } 0 & \text { Phase } 1 & \text { Phase } 2 & \text { Phase } 3\end{array}$

1 Crest of

greater

tuberosity
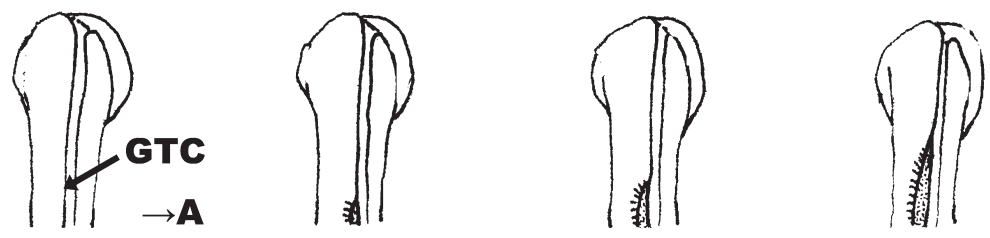

2 Crest of

lesser

tuberosity
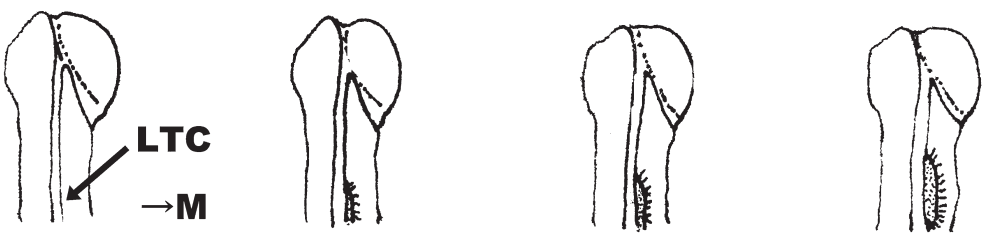

3 Deltoid tuberosity
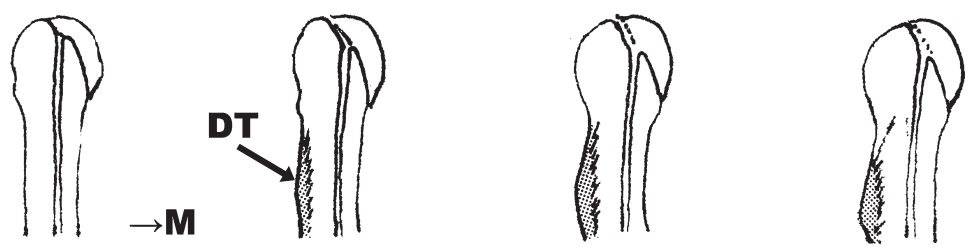

\section{Radial tuberosity}
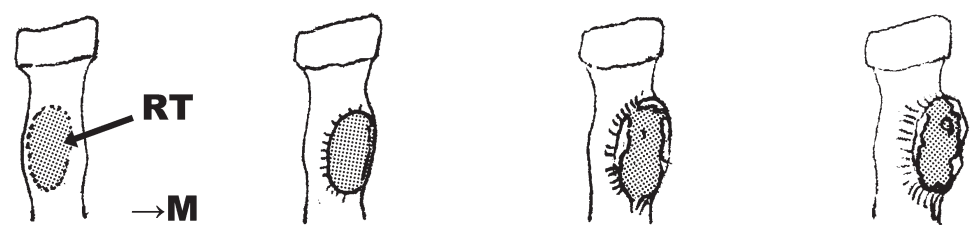

5 Olecranon
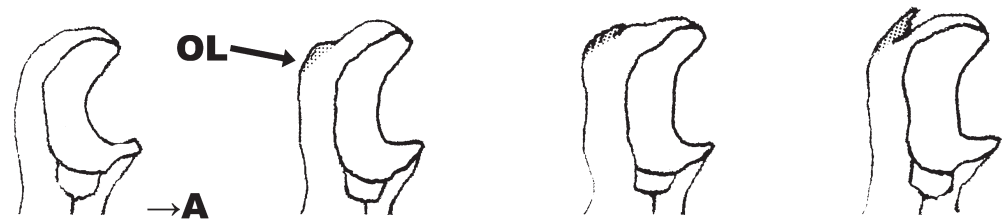

6 Supinator crest
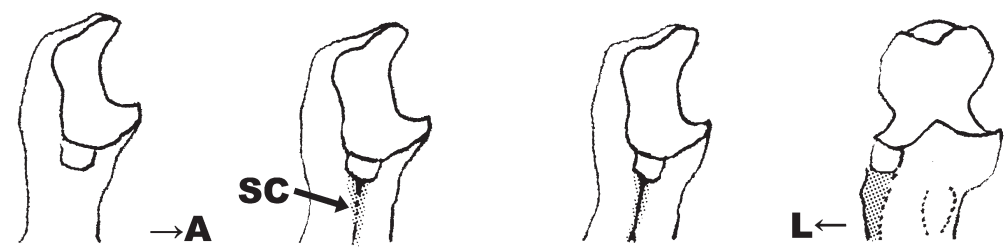

7 Ulnar tuberosity
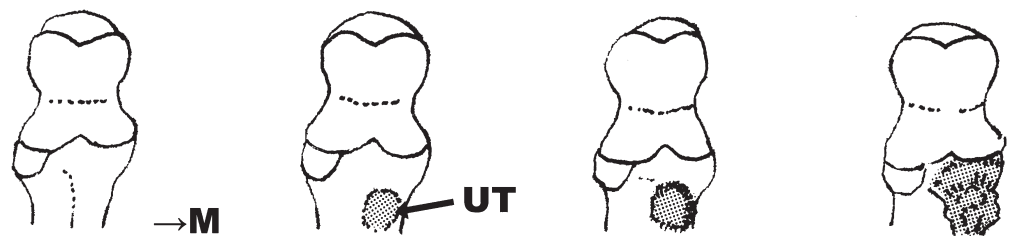

Figure 2. Schematic explanations of the advanced MSM scoring method used in this study: (a) upper limbs; (b) lower limbs. 
(b)

Phase 0 Phase 1 Phase 2 Phase 3

8 Greater trochanter

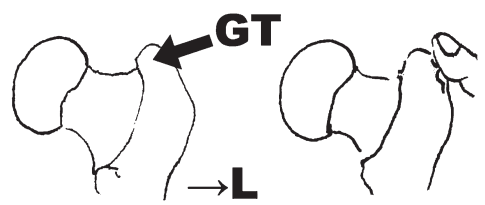<smiles>CCCCC1CCCCCC1CCC</smiles>

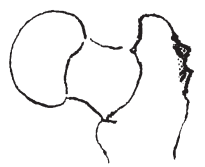

9 Lesser trochanter
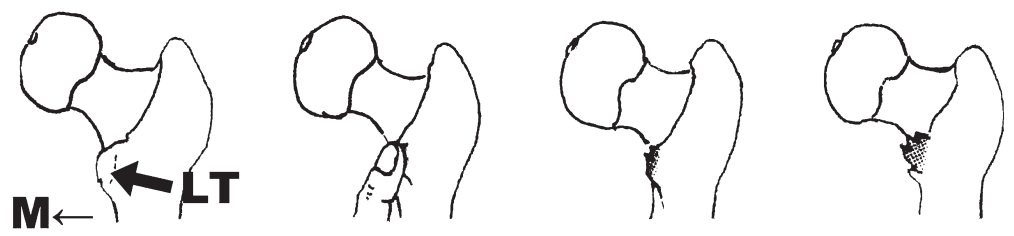

10 Gluteal tuberosity
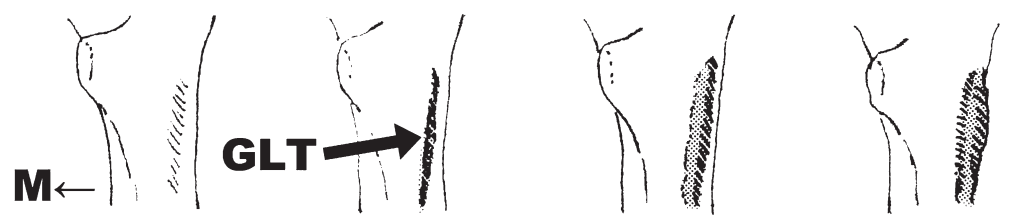

11 Linea aspera
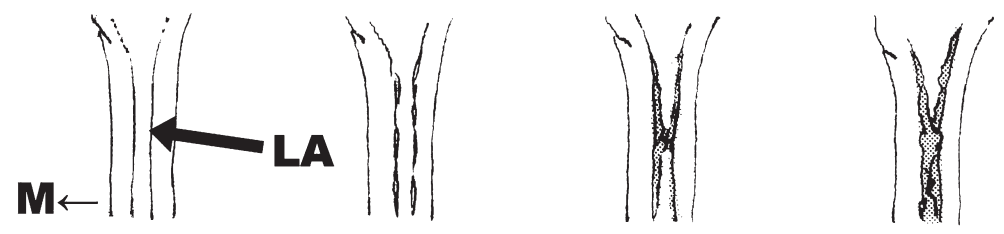

12 Patellar base
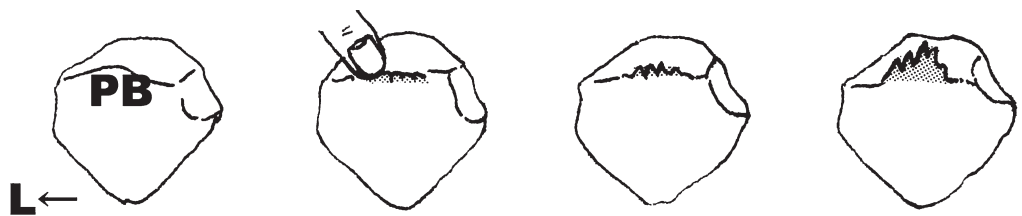

\section{Soleal}

line
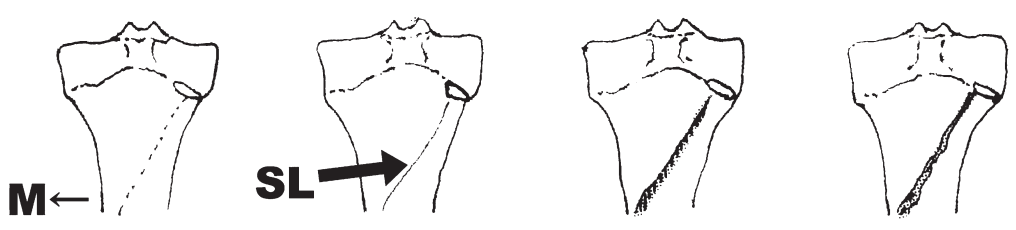

14 Tibial

tuberosity
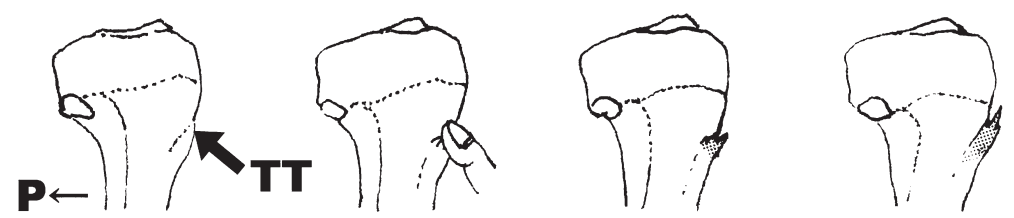

15 Calcaneal tuberosity
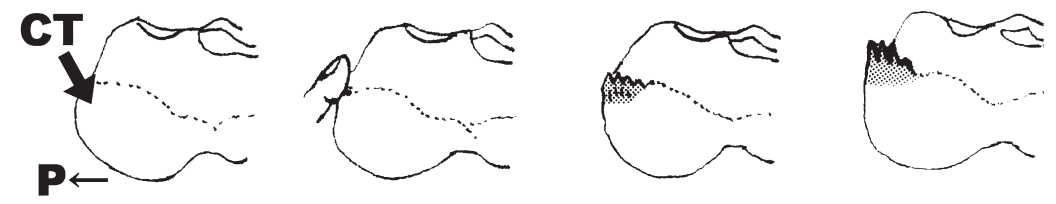

Figure 2. (continued) 
Table 2. Location of MSMs and corresponding muscles, and criteria for the advanced scores

\begin{tabular}{|c|c|c|c|c|c|c|c|}
\hline \multirow{2}{*}{ No. } & \multirow{2}{*}{ Element } & \multirow{2}{*}{$\begin{array}{c}\text { MSM traits } \\
\text { (Abbreviation) }\end{array}$} & \multirow{2}{*}{$\begin{array}{l}\text { Corresponding } \\
\text { muscles }\end{array}$} & \multicolumn{4}{|c|}{ Criteria for scoring MSM } \\
\hline & & & & Phase 0 & Phase 1 & Phase 2 & Phase 3 \\
\hline 1 & Humerus & $\begin{array}{l}\text { Crest of greater } \\
\text { tuberosity (GTC) }\end{array}$ & Pectoralis major & $\begin{array}{l}\text { Normal crest and no } \\
\text { depression }\end{array}$ & $\begin{array}{l}\text { Longitudinal irregular } \\
\text { depression below } \\
3 \mathrm{~mm} \text { at inferior level } \\
\text { of the crest }\end{array}$ & $\begin{array}{l}\text { Longitudinal irregular } \\
\text { depression over } 3 \mathrm{~mm} \text {, } \\
\text { below } 5 \mathrm{~mm} \text { at inferior } \\
\text { level of the crest }\end{array}$ & $\begin{array}{l}\text { Longitudinal irregular } \\
\text { depression over } 5 \mathrm{~mm} \\
\text { at inferior level of the } \\
\text { crest }\end{array}$ \\
\hline 2 & Humerus & $\begin{array}{l}\text { Crest of lesser } \\
\text { tuberosity (LTC) }\end{array}$ & $\begin{array}{l}\text { Teres major } \\
\text { Latissimus dorsi }\end{array}$ & $\begin{array}{l}\text { Normal crest and no } \\
\text { depression }\end{array}$ & $\begin{array}{l}\text { Longitudinal irregular } \\
\text { depression below } \\
3 \mathrm{~mm} \text { at inferior level } \\
\text { of the crest }\end{array}$ & $\begin{array}{l}\text { Longitudinal irregular } \\
\text { depression over } 3 \mathrm{~mm} \text {, } \\
\text { below } 5 \mathrm{~mm} \text { at inferior } \\
\text { level of the crest }\end{array}$ & $\begin{array}{l}\text { Longitudinal irregular } \\
\text { depression over } 5 \mathrm{~mm} \\
\text { at inferior level of the } \\
\text { crest }\end{array}$ \\
\hline 3 & Humerus & $\begin{array}{l}\text { Deltoid tuberosi- } \\
\text { ty (DT) }\end{array}$ & Deltoideus & $\begin{array}{l}\text { Unclear tuberosity and } \\
\text { lateral outline is } \\
\text { almost straight }\end{array}$ & $\begin{array}{l}\text { Slightly developed } \\
\text { tuberosity but lateral } \\
\text { outline is hardly } \\
\text { curved }\end{array}$ & $\begin{array}{l}\text { Developed tuberosity } \\
\text { and lateral outline is } \\
\text { smoothly curved }\end{array}$ & $\begin{array}{l}\text { Well-developed } \\
\text { tuberosity and lateral } \\
\text { outline is clearly } \\
\text { square }\end{array}$ \\
\hline 4 & Radius & $\begin{array}{l}\text { Radial tuberosity } \\
\text { (RT) }\end{array}$ & $\begin{array}{l}\text { Tendon of biceps } \\
\text { brachii }\end{array}$ & $\begin{array}{l}\text { Tuberosity is not } \\
\text { prominent and its } \\
\text { outline is flat }\end{array}$ & $\begin{array}{l}\text { Tuberosity is slightly } \\
\text { developed and forms a } \\
\text { part of medial outline } \\
\text { of diaphysis }\end{array}$ & $\begin{array}{l}\text { Outline of tuberosity } \\
\text { is prominent and } \\
\text { tuberosity surface tilts } \\
\text { medially }\end{array}$ & $\begin{array}{l}\text { Whole tuberosity is } \\
\text { prominent and tilts } \\
\text { medially, enthesophyte } \\
\text { is somewhat formed }\end{array}$ \\
\hline 5 & Ulna & Olecranon (OL) & $\begin{array}{l}\text { Tendon of triceps } \\
\text { brachii }\end{array}$ & $\begin{array}{l}\text { Superior edge of } \\
\text { olecranon is smooth } \\
\text { and no protuberance }\end{array}$ & $\begin{array}{l}\text { Tendon attachment of } \\
\text { olecranon is smoothly } \\
\text { developed below } \\
3 \mathrm{~mm} \text { in height }\end{array}$ & $\begin{array}{l}\text { Tendon attachment of } \\
\text { olecranon slightly } \\
\text { sharpens over } 3 \mathrm{~mm} \text {, } \\
\text { below } 5 \mathrm{~mm} \text { in height }\end{array}$ & $\begin{array}{l}\text { Tendon attachment of } \\
\text { olecranon is sharpely } \\
\text { developed over } 5 \mathrm{~mm} \\
\text { in height }\end{array}$ \\
\hline 6 & Ulna & $\begin{array}{l}\text { Supinator crest } \\
\text { (SC) }\end{array}$ & Supinator & $\begin{array}{l}\text { Indistinct crest inferior } \\
\text { to radial notch and } \\
\text { lateral surface is flat }\end{array}$ & $\begin{array}{l}\text { Plain crest inferior to } \\
\text { radial notch but lateral } \\
\text { surface is still flat }\end{array}$ & $\begin{array}{l}\text { Clear crest inferior to } \\
\text { radial notch and the } \\
\text { crest projects some- } \\
\text { what to lateral }\end{array}$ & $\begin{array}{l}\text { Crest projects more } \\
\text { lateral than outline of } \\
\text { radial notch }\end{array}$ \\
\hline 7 & Ulna & $\begin{array}{l}\text { Ulnar tuberosity } \\
\text { (UT) }\end{array}$ & Brachialis & $\begin{array}{l}\text { Inferior level of } \\
\text { coronoid process is } \\
\text { flat and tuberosity is } \\
\text { hardly prominent }\end{array}$ & $\begin{array}{l}\text { Tuberosity is slightly } \\
\text { prominent below } \\
3 \mathrm{~mm} \text { in height }\end{array}$ & $\begin{array}{l}\text { Tuberosity is clearly } \\
\text { developed and forms } \\
\text { irregular prominence } \\
\text { over } 3 \mathrm{~mm} \text {, below } \\
5 \mathrm{~mm} \text { in height }\end{array}$ & $\begin{array}{l}\text { Whole tuberosity is } \\
\text { developed and forms } \\
\text { some enthesophytes }\end{array}$ \\
\hline 8 & Femur & $\begin{array}{l}\text { Greater trochant- } \\
\text { er }(\mathrm{GT})\end{array}$ & $\begin{array}{l}\text { Gluteus medius and } \\
\text { minimus }\end{array}$ & $\begin{array}{l}\text { Surface of greater } \\
\text { trochanter is smooth } \\
\text { and no enthesophytes }\end{array}$ & $\begin{array}{l}\text { Slight enthesophytes } \\
\text { on the surface of } \\
\text { greater trochanter are } \\
\text { confirmed by palpa- } \\
\text { tion }\end{array}$ & $\begin{array}{l}\text { Clear enthesophytes } \\
\text { below } 3 \mathrm{~mm} \text { in length, } \\
\text { on the surface of } \\
\text { greater trochanter }\end{array}$ & $\begin{array}{l}\text { Severe enthesophytes } \\
\text { over } 3 \mathrm{~mm} \text { in length, } \\
\text { on the surface of } \\
\text { greater trochanter }\end{array}$ \\
\hline 9 & Femur & $\begin{array}{l}\text { Lesser trochanter } \\
\text { (LT) }\end{array}$ & $\begin{array}{l}\text { Iliopsoas (Psoas } \\
\text { major, Iliacus) }\end{array}$ & $\begin{array}{l}\text { Surface of lesser } \\
\text { trochanter is smooth } \\
\text { and no enthesophytes }\end{array}$ & $\begin{array}{l}\text { Slight enthesophytes } \\
\text { on the surface of lesser } \\
\text { trochanter are con- } \\
\text { firmed by palpation }\end{array}$ & $\begin{array}{l}\text { Clear enthesophytes } \\
\text { below } 3 \mathrm{~mm} \text { in length, } \\
\text { on the surface of lesser } \\
\text { trochanter }\end{array}$ & $\begin{array}{l}\text { Severe enthesophytes } \\
\text { over } 3 \mathrm{~mm} \text { in length, } \\
\text { on the surface of lesser } \\
\text { trochanter }\end{array}$ \\
\hline 10 & Femur & $\begin{array}{l}\text { Gluteal tuberosity } \\
\text { (GLT) }\end{array}$ & Gluteus maximus & $\begin{array}{l}\text { Surface is smooth and } \\
\text { flat, unclear tuberosity }\end{array}$ & $\begin{array}{l}\text { Whole tuberosity is } \\
\text { slightly rough but still } \\
\text { flat }\end{array}$ & $\begin{array}{l}\text { Tuberosity is rough } \\
\text { and projects below } \\
3 \mathrm{~mm} \text { in height }\end{array}$ & $\begin{array}{l}\text { Whole tuberosity } \\
\text { projects over } 3 \mathrm{~mm} \text { in } \\
\text { height, occasionally } \\
\text { the third trochanter }\end{array}$ \\
\hline 11 & Femur & $\begin{array}{l}\text { Linea aspera; } \\
\text { lateral and medial } \\
\text { lips (LA) }\end{array}$ & $\begin{array}{l}\text { Adductor magnus, } \\
\text { longus, and brevis } \\
\text { Medial and lateral } \\
\text { vastus of quadriceps } \\
\text { femoris } \\
\text { Short head of biceps } \\
\text { femoris }\end{array}$ & $\begin{array}{l}\text { Surface of linea aspera } \\
\text { is smooth and both } \\
\text { lateral and medial lips } \\
\text { are plain, and able to } \\
\text { distinguish them }\end{array}$ & $\begin{array}{l}\text { Both lips project } \\
\text { slightly as broken } \\
\text { lines, lateral lip } \\
\text { separates from medial } \\
\text { lip }\end{array}$ & $\begin{array}{l}\text { Projection of linea } \\
\text { aspera below } 3 \mathrm{~mm} \text { in } \\
\text { height, partly one lip } \\
\text { is close to other lip }\end{array}$ & $\begin{array}{l}\text { Projection of linea } \\
\text { aspera over } 3 \mathrm{~mm} \text { in } \\
\text { height, both lips } \\
\text { connect and difficult } \\
\text { to distinguish them }\end{array}$ \\
\hline 12 & Patella & $\begin{array}{l}\text { Patellar base } \\
\text { (PB) }\end{array}$ & $\begin{array}{l}\text { Tendon of quadri- } \\
\text { ceps femoris }\end{array}$ & $\begin{array}{l}\text { Superior edge of } \\
\text { patellar base is smooth } \\
\text { and no enthesophytes }\end{array}$ & $\begin{array}{l}\text { Slight enthesophytes } \\
\text { on the superior edge of } \\
\text { patellar base is } \\
\text { confirmed by palpa- } \\
\text { tion }\end{array}$ & $\begin{array}{l}\text { Clear enthesophytes } \\
\text { below } 3 \mathrm{~mm} \text { in length, } \\
\text { on the superior edge of } \\
\text { patellar base }\end{array}$ & $\begin{array}{l}\text { Severe enthesophytes } \\
\text { over } 3 \mathrm{~mm} \text { in length, } \\
\text { on the superior edge of } \\
\text { patellar base }\end{array}$ \\
\hline 13 & Tibia & Soleal line (SL) & $\begin{array}{l}\text { Soleus in triceps } \\
\text { surae }\end{array}$ & $\begin{array}{l}\text { No soleal line or } \\
\text { broken line, posterior } \\
\text { surface of tibia is flat }\end{array}$ & $\begin{array}{l}\text { Clear soleal line but } \\
\text { no prominence }\end{array}$ & $\begin{array}{l}\text { Clear soleal line and } \\
\text { prominent below } \\
3 \mathrm{~mm} \text { in height }\end{array}$ & $\begin{array}{l}\text { Remarkable soleal line } \\
\text { and prominent over } \\
3 \mathrm{~mm} \text { in height }\end{array}$ \\
\hline 14 & Tibia & $\begin{array}{l}\text { Tibial tuberosity } \\
\text { (TT) }\end{array}$ & $\begin{array}{l}\text { Patellar ligament } \\
\text { attached to quadri- } \\
\text { ceps femoris }\end{array}$ & $\begin{array}{l}\text { Superior edge of } \\
\text { tuberosity is smooth } \\
\text { and no enthesophytes }\end{array}$ & $\begin{array}{l}\text { Slight enthesophytes } \\
\text { on the superior edge } \\
\text { are confirmed by } \\
\text { palpation }\end{array}$ & $\begin{array}{l}\text { Clear enthesophytes } \\
\text { below } 3 \mathrm{~mm} \text { in length, } \\
\text { on the superior edge }\end{array}$ & $\begin{array}{l}\text { Severe enthesophytes } \\
\text { over } 3 \mathrm{~mm} \text { in length, } \\
\text { on the superior edge }\end{array}$ \\
\hline 15 & Calcaneus & $\begin{array}{l}\text { Calcaneal } \\
\text { tuberosity (CT) }\end{array}$ & $\begin{array}{l}\text { Calcaneal tendon in } \\
\text { triceps surae }\end{array}$ & $\begin{array}{l}\text { Posterior of calcaneal } \\
\text { tuberosity is smooth } \\
\text { and no enthesophytes }\end{array}$ & $\begin{array}{l}\text { Slight enthesophytes } \\
\text { on the posterior area } \\
\text { of tuberosity are } \\
\text { confirmed by palpa- } \\
\text { tion }\end{array}$ & $\begin{array}{l}\text { Clear enthesophytes } \\
\text { below } 3 \mathrm{~mm} \text { in length, } \\
\text { on the posterior area } \\
\text { of tuberosity }\end{array}$ & $\begin{array}{l}\text { Severe enthesophytes } \\
\text { over } 3 \mathrm{~mm} \text { in length, } \\
\text { on the posterior area } \\
\text { of tuberosity }\end{array}$ \\
\hline
\end{tabular}



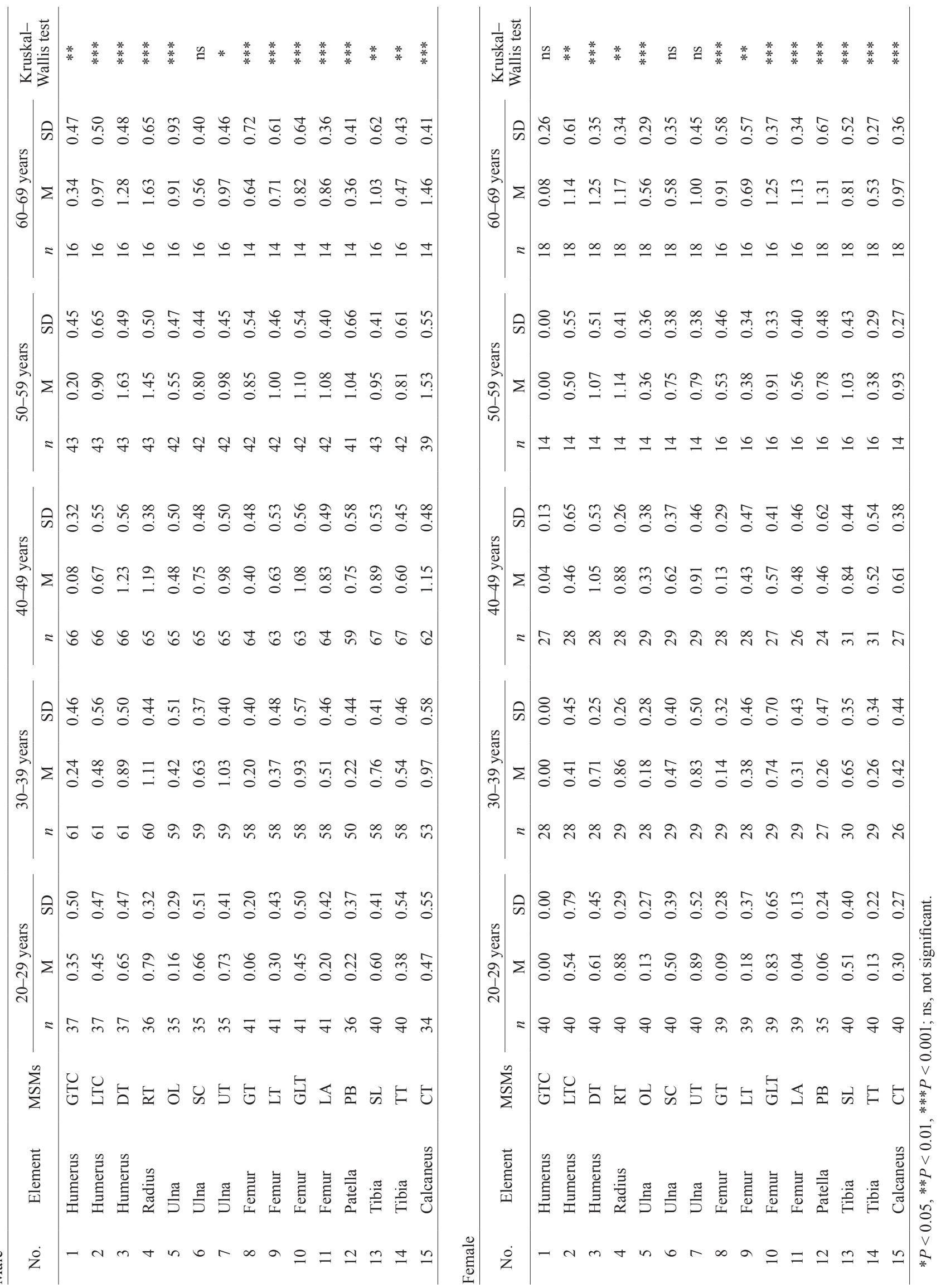
(a)
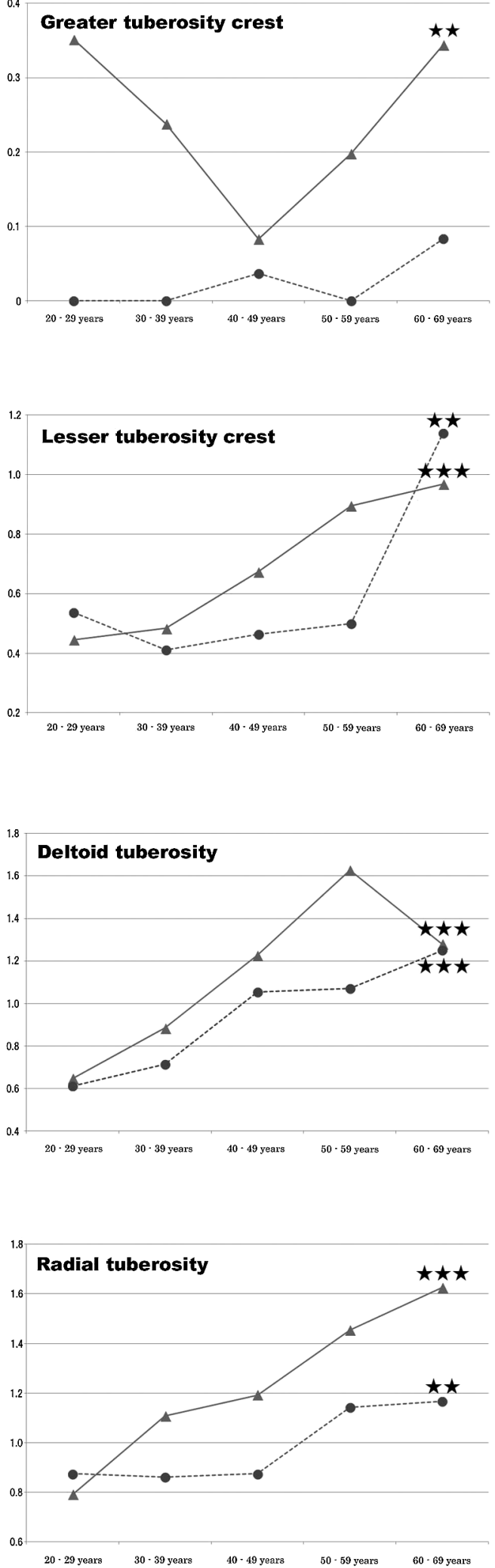
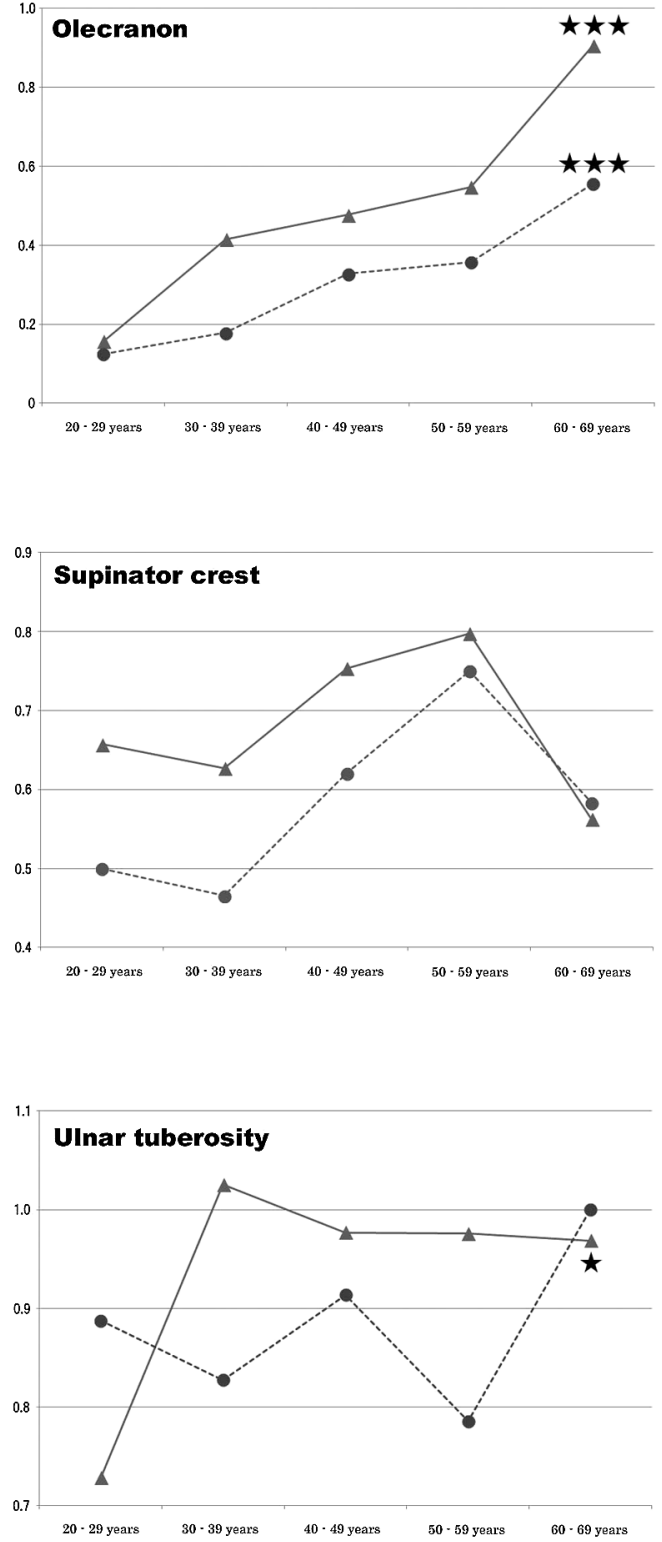

$\Delta:$ Male

: Female

Results of Kruskal-Wallis tests among total age classes

$$
\begin{aligned}
& \star: \mathrm{P}<0.05 \\
& \star \star: \mathrm{P}<0.01 \\
& \star \star \star: \mathrm{P}<0.001
\end{aligned}
$$

Figure 3. Line graphs of MSM score in each age class: (a) upper limbs; (b) lower limbs. 
(b)
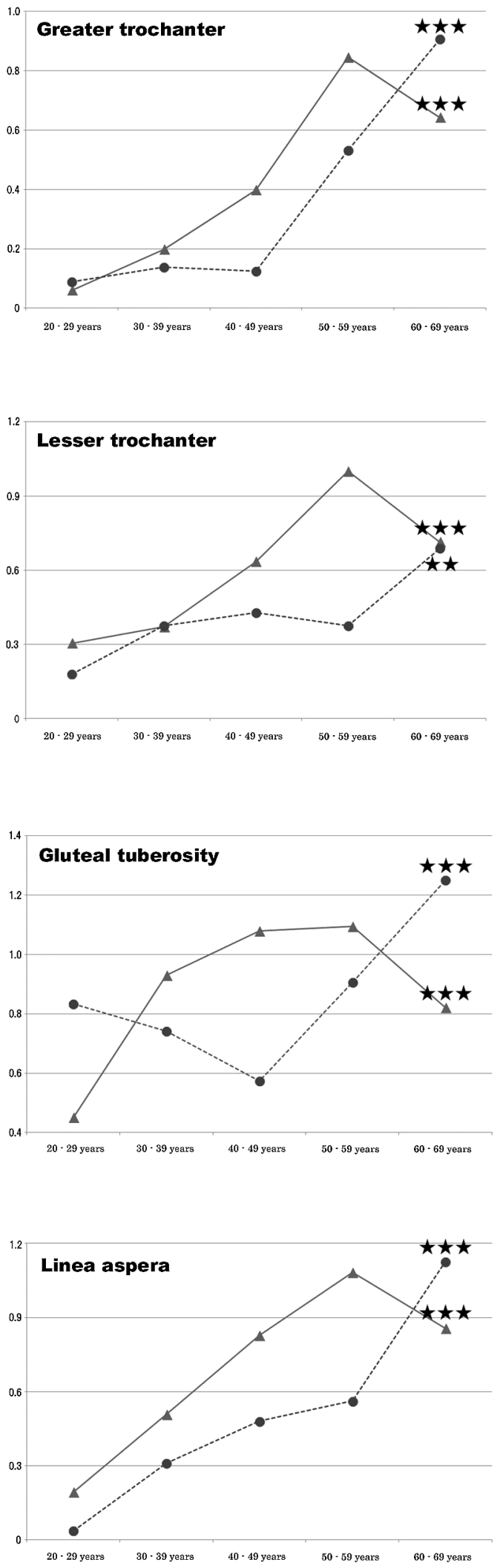
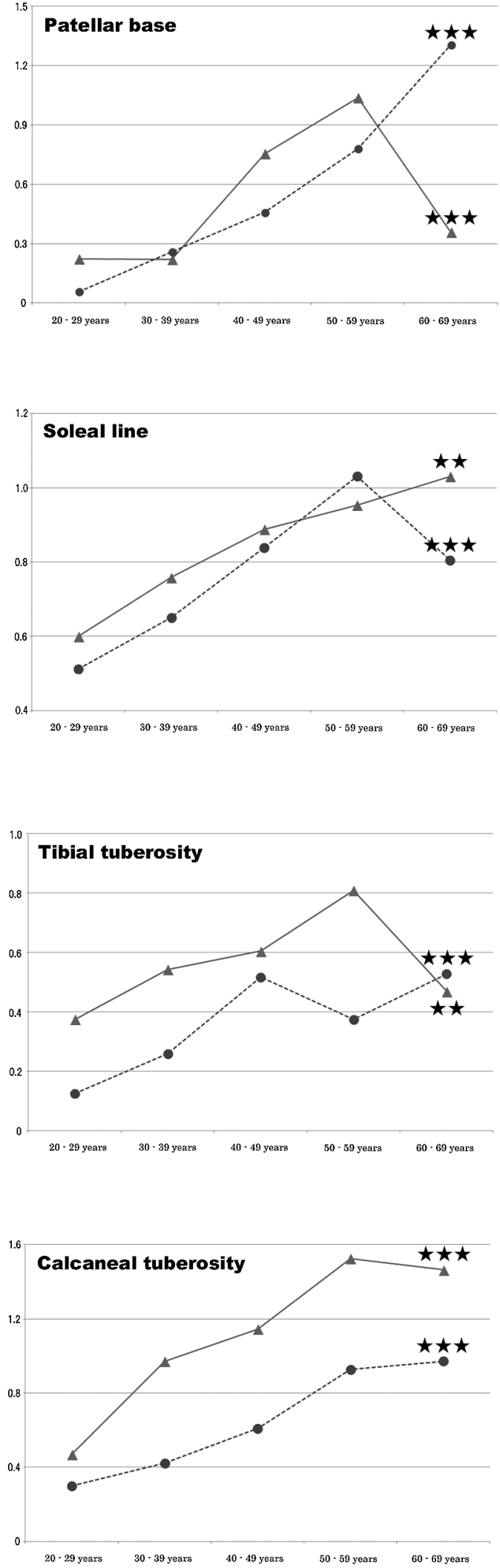

Figure 3. (continued) 
Table 4. Pearson's correlation coefficients between age-at-death and MSM score

\begin{tabular}{|c|c|c|c|c|c|c|c|c|c|c|}
\hline \multirow{2}{*}{ No. } & \multirow{2}{*}{ Element } & \multirow{2}{*}{ MSMs } & \multicolumn{4}{|c|}{ Male } & \multicolumn{4}{|c|}{ Female } \\
\hline & & & $n$ & $R$ & $P$ & & $n$ & $R$ & $P$ & \\
\hline 1 & Humerus & GTC & 223 & -0.0736 & 0.2738 & ns & 127 & 0.2148 & 0.0153 & $*$ \\
\hline 2 & Humerus & LTC & 223 & 0.3060 & 3.E-06 & $* * *$ & 128 & 0.2236 & 0.0112 & $*$ \\
\hline 3 & Humerus & DT & 223 & 0.4968 & 3.E-15 & $* * *$ & 128 & 0.4843 & 7.E-09 & $* * *$ \\
\hline 4 & Radius & RT & 220 & 0.4523 & 2.E-12 & $* * *$ & 129 & 0.3732 & 1.E-05 & $* * *$ \\
\hline 5 & Ulna & $\mathrm{OL}$ & 217 & 0.3108 & 3.E-06 & $* * *$ & 129 & 0.4191 & 8.E-07 & $* * *$ \\
\hline 6 & Ulna & $\mathrm{SC}$ & 217 & 0.0610 & 0.3712 & ns & 130 & 0.1770 & 0.0440 & $*$ \\
\hline 7 & Ulna & UT & 217 & 0.1503 & 0.0268 & $*$ & 130 & 0.0401 & 0.6509 & ns \\
\hline 8 & Femur & GT & 219 & 0.4560 & 1.E-12 & $* * *$ & 128 & 0.5168 & 4.E-10 & $* * *$ \\
\hline 9 & Femur & LT & 218 & 0.3937 & 2.E-09 & $* * *$ & 127 & 0.3214 & 0.0002 & $* * *$ \\
\hline 10 & Femur & GLT & 218 & 0.2638 & 0.0001 & $* * *$ & 127 & 0.1742 & 0.0501 & ns \\
\hline 11 & Femur & LA & 219 & 0.5438 & $0 . \mathrm{E}+00$ & $* * *$ & 126 & 0.6925 & $0 . \mathrm{E}+00$ & $* * *$ \\
\hline 12 & Patella & $\mathrm{PB}$ & 200 & 0.3800 & 3.E-08 & $* * *$ & 120 & 0.6684 & 1.E-16 & $* * *$ \\
\hline 13 & Tibia & $\mathrm{SL}$ & 224 & 0.2646 & 0.0001 & $* * *$ & 135 & 0.3127 & 0.0002 & $* * *$ \\
\hline 14 & Tibia & TT & 223 & 0.1749 & 0.0089 & $* *$ & 134 & 0.3535 & 3.E-05 & $* * *$ \\
\hline 15 & Calcaneus & $\mathrm{CT}$ & 202 & 0.4921 & 1.E-13 & $* * *$ & 125 & 0.5838 & 9.E-13 & $* * *$ \\
\hline
\end{tabular}

$n$, sample size; $R$, correlation coeffient; $P$, probability of significant test.

$* P<0.05, * * P<0.01, * * * P<0.001 ;$ ns, not significant.

response to aging, in particular at 30-59 years of age. The present results support findings in previous studies based on archaeological and contemporary materials that suggest a relationship between MSM expression and age.

Although the scores of many MSMs increased with age, sex differences were observed at higher age stages in several MSMs, especially of the lower limb (DT, GT, LT, GLT, LA, PB, TT, and CT). For these MSMs, the male scores of the age stage of 50-59 years were highest and those of the later age stage (60-69 years) declined. In females, MSM scores increased steadily from the stage of 20-29 years to the stage of 60-69 years. This sex difference is probably related to males retiring from work. Because Japanese males from the late 19 th to early 20 th centuries retired in their $50 \mathrm{~s}-60 \mathrm{~s}$, daily muscular activity level and loading of the limb skeleton by labor might have decreased after the stage of 50-59 years and the related MSMs also exhibited lower scores. On the other hand, the continuous increase of MSM scores in senile females may be explained from the view of cortical wasting in the long bones. Wescott and Child (2009) pointed out that MSM expression following immobility was pronounced, despite reduced cross-sectional geometric parameters such as clinical cases with cerebral palsy. Total bone mass of senile females after menopause tends to diminish and, in connection with this, cortical bone also wastes from this period. As a result, cortical wasting in senile females might contribute to stronger MSM expression.

\section{Temporal comparisons}

Many MSMs showed significant inter-population differences $(9 / 15$ in younger adult males, $11 / 15$ in older adult males, $11 / 15$ in younger adult females, and $10 / 15$ in older adult females) among the Yoshigo Jomon, Doigahama Yayoi, and modern Japanese in each of the younger adult and older adult groups (Table 5).

As for the age-related difference, between the younger adult and older adult groups, most MSMs had no significant differences in the Yoshigo Jomon and Doigahama Yayoi $(11 / 15$ in males and $12 / 15$ in females of the Yoshigo Jomon, and $12 / 15$ in males and $9 / 15$ in females of the Doigahama
Yayoi) (Table 6). In contrast, most MSMs of modern Japanese differed significantly between these age groups (13/15 in males, 10/15 in females). Activities performed by younger adults amongst the Yoshigo Jomon and Doigahama Yayoi were likely accentuated compared to those experienced by modern Japanese. It is possible that these prehistoric groups began intensive activity at earlier ages. Okazaki (2007) inferred that Jomon children were already participating in hunting or gathering by adolescence based on allometrical analysis of cross-sectional parameters in juvenile limb bones.

The age differences for modern Japanese were large in both males and females. The physical activities performed by modern younger adults might have been easier than those of older adults due to the reduction of musculoskeletal load by industrialized modern lifestyles. Plus, older adult males of modern Japanese had a number of MSM scores greater than those of the Yoshigo Jomon and Doigahama Yayoi. These modern Japanese lived a longer life than prehistoric groups and delayed the beginning of heavy physical labor until adulthood. Thus, it is probable that cumulative loading promoted MSM expression at the age stage of 40-59 years.

In the two-dimensional plot of PC scores, the configurations of the younger adults (20-39 years) were different from those of the older adults (40-59 years). However, as mentioned above, there were no significant differences in most MSMs between these two age classes in the prehistoric Jomon and Yayoi groups. Therefore, pooling the adult age classes in these prehistoric populations would not be problematic. Modern Japanese, however, had significant differences between the adult age classes, and so modern mixed data should be utilized carefully when it is used as a control group in comparisons of various prehistoric groups.

\section{Acknowledgments}

The author is grateful to the following people for permission to analyze materials: Dr. Katayama K. and Dr. Nakatsukasa M. (Department of Science, Kyoto University), Dr. Matsuno Y. and Dr. Miyaso H. (Graduate School of 
Table 5. Basic statistics in each period and results of Kruskal-Wallis tests

Younger adult male

\begin{tabular}{|c|c|c|c|c|c|c|c|c|c|c|c|c|}
\hline \multirow{2}{*}{ No. } & \multirow{2}{*}{ Element } & \multirow{2}{*}{ MSMs } & \multicolumn{3}{|c|}{ Yoshigo Jomon } & \multicolumn{3}{|c|}{ Doigahama Yayoi } & \multicolumn{3}{|c|}{ Modern Japanese } & \multirow{2}{*}{$\begin{array}{l}\text { Kruskal- } \\
\text { Wallis test }\end{array}$} \\
\hline & & & $n$ & $\mathrm{M}$ & SD & $n$ & M & SD & $n$ & $\mathrm{M}$ & SD & \\
\hline 1 & Humerus & GTC & 40 & 0.95 & 0.57 & 17 & 0.59 & 0.51 & 99 & 0.28 & 0.47 & $* * *$ \\
\hline 2 & Humerus & LTC & 41 & 0.71 & 0.55 & 17 & 0.65 & 0.49 & 99 & 0.47 & 0.52 & $*$ \\
\hline 3 & Humerus & DT & 44 & 1.06 & 0.63 & 16 & 0.56 & 0.44 & 99 & 0.80 & 0.51 & ** \\
\hline 4 & Radius & RT & 35 & 0.96 & 0.51 & 15 & 1.00 & 0.50 & 97 & 0.99 & 0.44 & $\mathrm{~ns}$ \\
\hline 5 & Ulna & $\mathrm{OL}$ & 39 & 0.27 & 0.40 & 15 & 0.17 & 0.36 & 95 & 0.32 & 0.46 & ns \\
\hline 6 & Ulna & $\mathrm{SC}$ & 45 & 1.11 & 0.60 & 15 & 0.47 & 0.52 & 95 & 0.64 & 0.43 & $* * *$ \\
\hline 7 & Ulna & UT & 46 & 0.92 & 0.40 & 18 & 0.53 & 0.50 & 95 & 0.92 & 0.43 & $* *$ \\
\hline 8 & Femur & GT & 37 & 0.49 & 0.49 & 9 & 0.11 & 0.33 & 100 & 0.14 & 0.33 & $* * *$ \\
\hline 9 & Femur & LT & 38 & 0.37 & 0.58 & 13 & 0.69 & 0.48 & 100 & 0.35 & 0.46 & $*$ \\
\hline 10 & Femur & GLT & 48 & 0.45 & 0.53 & 14 & 0.86 & 0.53 & 100 & 0.74 & 0.59 & $*$ \\
\hline 11 & Femur & LA & 52 & 0.57 & 0.53 & 15 & 0.63 & 0.67 & 100 & 0.38 & 0.47 & $\mathrm{~ns}$ \\
\hline 12 & Patella & $\mathrm{PB}$ & 18 & 0.47 & 0.43 & 14 & 0.57 & 0.76 & 87 & 0.22 & 0.41 & $* *$ \\
\hline 13 & Tibia & SL & 37 & 0.59 & 0.43 & 16 & 1.03 & 0.62 & 99 & 0.69 & 0.42 & ns \\
\hline 14 & Tibia & $\mathrm{TT}$ & 29 & 0.74 & 0.67 & 12 & 0.50 & 0.52 & 99 & 0.48 & 0.50 & ns \\
\hline 15 & Calcaneus & CT & 33 & 0.97 & 0.76 & 12 & 0.75 & 0.62 & 88 & 0.78 & 0.62 & ns \\
\hline Averag & & & & 0.71 & & & 0.61 & & & 0.55 & & \\
\hline
\end{tabular}

Older adult male

\begin{tabular}{|c|c|c|c|c|c|c|c|c|c|c|c|c|}
\hline \multirow{2}{*}{ No. } & \multirow{2}{*}{ Element } & \multirow{2}{*}{ MSMs } & \multicolumn{3}{|c|}{ Yoshigo Jomon } & \multicolumn{3}{|c|}{ Doigahama Yayoi } & \multicolumn{3}{|c|}{ Modern Japanese } & \multirow{2}{*}{$\begin{array}{l}\text { Kruskal- } \\
\text { Wallis test }\end{array}$} \\
\hline & & & $n$ & M & SD & $n$ & $\mathrm{M}$ & SD & $n$ & M & SD & \\
\hline 1 & Humerus & GTC & 56 & 1.04 & 0.48 & 38 & 0.82 & 0.39 & 110 & 0.13 & 0.38 & *** \\
\hline 2 & Humerus & LTC & 56 & 0.66 & 0.51 & 38 & 0.58 & 0.50 & 110 & 0.76 & 0.60 & ns \\
\hline 3 & Humerus & DT & 59 & 1.21 & 0.57 & 42 & 0.86 & 0.40 & 110 & 1.39 & 0.56 & $* * *$ \\
\hline 4 & Radius & RT & 54 & 1.06 & 0.46 & 40 & 1.14 & 0.57 & 109 & 1.30 & 0.45 & $* *$ \\
\hline 5 & Ulna & $\mathrm{OL}$ & 55 & 0.17 & 0.34 & 34 & 0.29 & 0.43 & 108 & 0.50 & 0.49 & $* * *$ \\
\hline 6 & Ulna & $\mathrm{SC}$ & 63 & 1.07 & 0.51 & 36 & 0.56 & 0.61 & 108 & 0.77 & 0.46 & $* * *$ \\
\hline 7 & Ulna & UT & 62 & 0.90 & 0.53 & 38 & 0.53 & 0.49 & 108 & 0.98 & 0.48 & $* * *$ \\
\hline 8 & Femur & GT & 48 & 0.50 & 0.56 & 23 & 0.48 & 0.59 & 107 & 0.58 & 0.55 & ns \\
\hline 9 & Femur & LT & 50 & 0.44 & 0.51 & 35 & 0.80 & 0.63 & 106 & 0.78 & 0.53 & $* *$ \\
\hline 10 & Femur & GLT & 65 & 0.70 & 0.59 & 43 & 0.98 & 0.58 & 106 & 1.09 & 0.55 & $* * *$ \\
\hline 11 & Femur & LA & 66 & 0.86 & 0.55 & 47 & 0.81 & 0.66 & 107 & 0.93 & 0.47 & ns \\
\hline 12 & Patella & $\mathrm{PB}$ & 36 & 1.17 & 0.64 & 34 & 0.85 & 0.69 & 101 & 0.87 & 0.63 & $*$ \\
\hline 13 & Tibia & SL & 59 & 0.80 & 0.60 & 46 & 1.04 & 0.46 & 111 & 0.91 & 0.48 & $*$ \\
\hline 14 & Tibia & TT & 45 & 0.58 & 0.60 & 30 & 0.95 & 0.50 & 110 & 0.69 & 0.53 & $* *$ \\
\hline 15 & Calcaneus & CT & 55 & 1.35 & 0.64 & 30 & 1.27 & 0.45 & 102 & 1.29 & 0.54 & ns \\
\hline Average & & & & 0.83 & & & 0.80 & & & 0.86 & & \\
\hline
\end{tabular}

Younger adult female

\begin{tabular}{|c|c|c|c|c|c|c|c|c|c|c|c|c|}
\hline \multirow{2}{*}{ No. } & \multirow{2}{*}{ Element } & \multirow{2}{*}{ MSMs } & \multicolumn{3}{|c|}{ Yoshigo Jomon } & \multicolumn{3}{|c|}{ Doigahama Yayoi } & \multicolumn{3}{|c|}{ Modern Japanese } & \multirow{2}{*}{$\begin{array}{l}\text { Kruskal- } \\
\text { Wallis test }\end{array}$} \\
\hline & & & $n$ & M & SD & $n$ & M & SD & $n$ & M & SD & \\
\hline 1 & Humerus & GTC & 47 & 0.99 & 0.47 & 27 & 0.85 & 0.36 & 68 & 0.00 & 0.00 & $* * *$ \\
\hline 2 & Humerus & LTC & 50 & 0.72 & 0.52 & 27 & 0.52 & 0.49 & 68 & 0.49 & 0.67 & $*$ \\
\hline 3 & Humerus & DT & 53 & 0.78 & 0.64 & 29 & 0.40 & 0.34 & 68 & 0.65 & 0.38 & $* *$ \\
\hline 4 & Radius & RT & 55 & 1.16 & 0.49 & 22 & 0.52 & 0.45 & 69 & 0.87 & 0.28 & $* * *$ \\
\hline 5 & Ulna & $\mathrm{OL}$ & 53 & 0.10 & 0.27 & 24 & 0.00 & 0.00 & 68 & 0.15 & 0.27 & $*$ \\
\hline 6 & Ulna & $\mathrm{SC}$ & 57 & 0.98 & 0.68 & 27 & 0.19 & 0.40 & 69 & 0.49 & 0.39 & $* * *$ \\
\hline 7 & Ulna & UT & 57 & 0.93 & 0.40 & 26 & 0.54 & 0.51 & 69 & 0.86 & 0.51 & $* *$ \\
\hline 8 & Femur & GT & 44 & 0.52 & 0.59 & 20 & 0.15 & 0.37 & 68 & 0.11 & 0.30 & $* * *$ \\
\hline 9 & Femur & LT & 45 & 0.48 & 0.49 & 24 & 0.63 & 0.49 & 67 & 0.26 & 0.42 & $* *$ \\
\hline 10 & Femur & GLT & 60 & 0.71 & 0.60 & 25 & 0.62 & 0.53 & 68 & 0.79 & 0.67 & ns \\
\hline 11 & Femur & LA & 64 & 0.36 & 0.46 & 26 & 0.15 & 0.37 & 68 & 0.15 & 0.33 & $*$ \\
\hline 12 & Patella & $\mathrm{PB}$ & 36 & 0.25 & 0.43 & 18 & 0.31 & 0.42 & 62 & 0.15 & 0.37 & ns \\
\hline 13 & Tibia & SL & 60 & 0.68 & 0.42 & 26 & 0.58 & 0.27 & 70 & 0.57 & 0.38 & ns \\
\hline 14 & Tibia & TT & 53 & 0.17 & 0.36 & 19 & 0.32 & 0.48 & 69 & 0.18 & 0.28 & ns \\
\hline 15 & Calcaneus & CT & 47 & 0.98 & 0.68 & 19 & 0.55 & 0.69 & 66 & 0.35 & 0.35 & $* * *$ \\
\hline Average & & & & 0.65 & & & 0.42 & & & 0.40 & & \\
\hline
\end{tabular}

Older adult female

\begin{tabular}{|c|c|c|c|c|c|c|c|c|c|c|c|c|}
\hline \multirow{2}{*}{ No. } & \multirow{2}{*}{ Element } & \multirow{2}{*}{ MSMs } & \multicolumn{3}{|c|}{ Yoshigo Jomon } & \multicolumn{3}{|c|}{ Doigahama Yayoi } & \multicolumn{3}{|c|}{ Modern Japanese } & \multirow{2}{*}{$\begin{array}{c}\text { Kruskal- } \\
\text { Wallis test }\end{array}$} \\
\hline & & & $n$ & $\mathrm{M}$ & $\mathrm{SD}$ & $n$ & $\mathrm{M}$ & SD & $n$ & $\mathrm{M}$ & SD & \\
\hline 1 & Humerus & GTC & 39 & 1.11 & 0.47 & 24 & 0.65 & 0.48 & 41 & 0.02 & 0.11 & $* * *$ \\
\hline 2 & Humerus & LTC & 34 & 0.68 & 0.52 & 23 & 0.41 & 0.49 & 41 & 0.48 & 0.61 & $*$ \\
\hline 3 & Humerus & DT & 41 & 0.91 & 0.74 & 24 & 0.52 & 0.31 & 41 & 1.07 & 0.52 & $* * *$ \\
\hline 4 & Radius & RT & 35 & 1.23 & 0.47 & 23 & 0.83 & 0.32 & 41 & 0.97 & 0.34 & $* *$ \\
\hline 5 & Ulna & $\mathrm{OL}$ & 33 & 0.25 & 0.40 & 22 & 0.32 & 0.65 & 42 & 0.35 & 0.37 & ns \\
\hline 6 & Ulna & $\mathrm{SC}$ & 41 & 0.88 & 0.55 & 24 & 0.46 & 0.51 & 42 & 0.68 & 0.37 & $*$ \\
\hline 7 & Ulna & UT & 41 & 0.82 & 0.36 & 24 & 0.65 & 0.48 & 42 & 0.85 & 0.44 & ns \\
\hline 8 & Femur & GT & 33 & 0.62 & 0.57 & 18 & 0.31 & 0.46 & 43 & 0.31 & 0.41 & $*$ \\
\hline 9 & Femur & LT & 30 & 0.61 & 0.44 & 22 & 0.61 & 0.65 & 43 & 0.41 & 0.42 & ns \\
\hline 10 & Femur & GLT & 40 & 0.92 & 0.43 & 22 & 0.95 & 0.43 & 42 & 0.73 & 0.41 & $*$ \\
\hline 11 & Femur & LA & 49 & 0.48 & 0.53 & 22 & 0.36 & 0.44 & 41 & 0.53 & 0.43 & ns \\
\hline 12 & Patella & $\mathrm{PB}$ & 23 & 0.61 & 0.71 & 15 & 0.57 & 0.70 & 38 & 0.64 & 0.59 & ns \\
\hline 13 & Tibia & SL & 36 & 0.90 & 0.53 & 22 & 0.68 & 0.25 & 45 & 0.91 & 0.44 & $*$ \\
\hline 14 & Tibia & TT & 21 & 0.21 & 0.37 & 18 & 0.72 & 0.43 & 45 & 0.46 & 0.47 & $* * *$ \\
\hline 15 & Calcaneus & CT & 34 & 1.39 & 0.57 & 19 & 0.84 & 0.60 & 40 & 0.73 & 0.37 & $* * *$ \\
\hline Average & & & & 0.77 & & & 0.59 & & & 0.61 & & \\
\hline
\end{tabular}

$* P<0.05,{ }^{* *} P<0.01,{ }^{* * *} P<0.001 ;$ ns, not significant. 
(a)

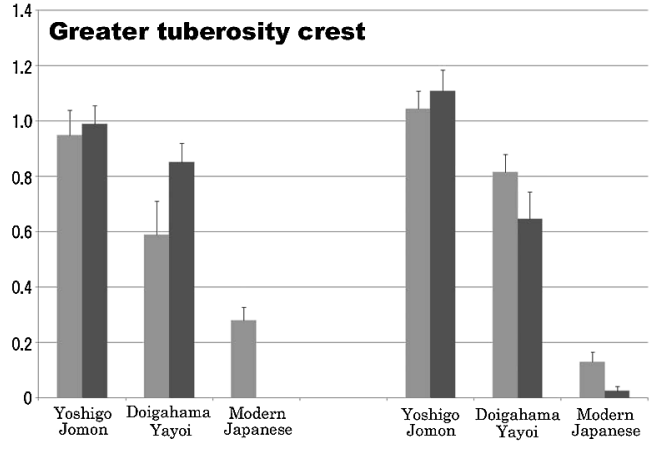

20 - 39 years
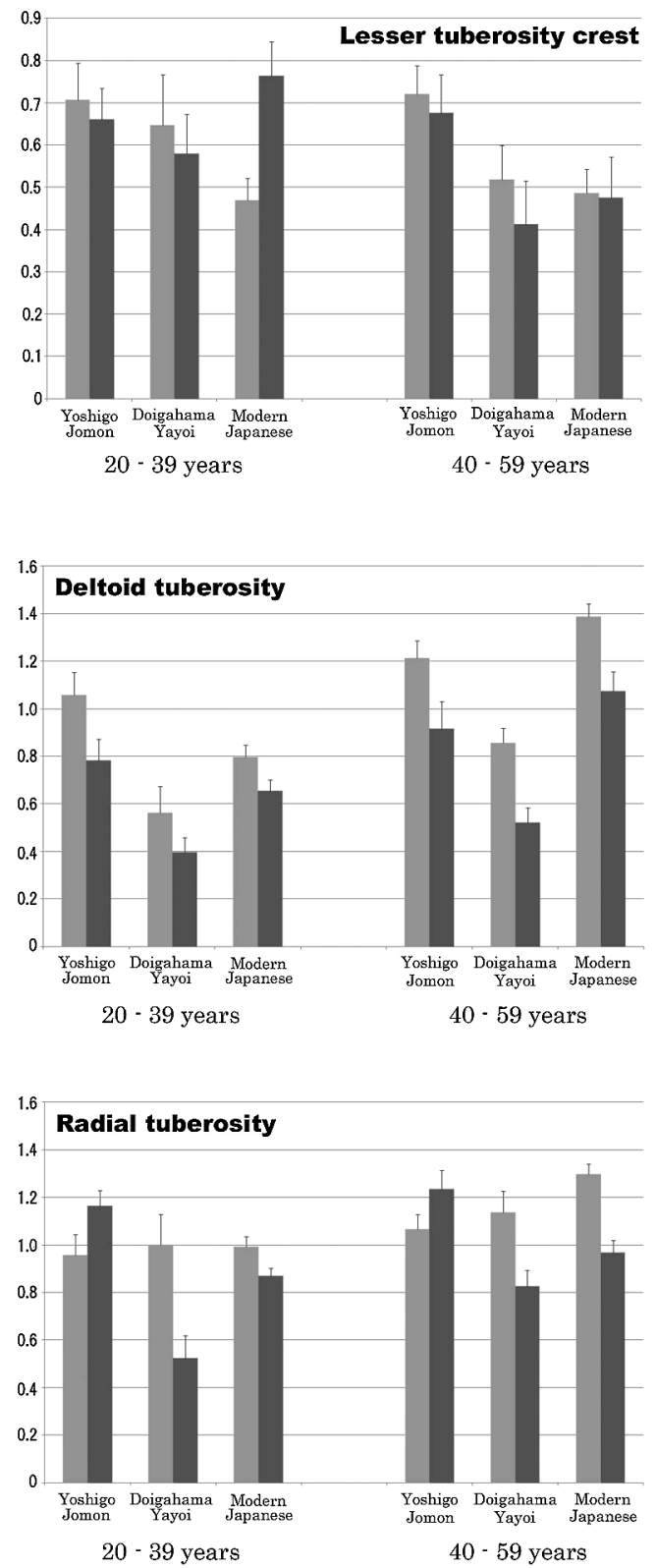
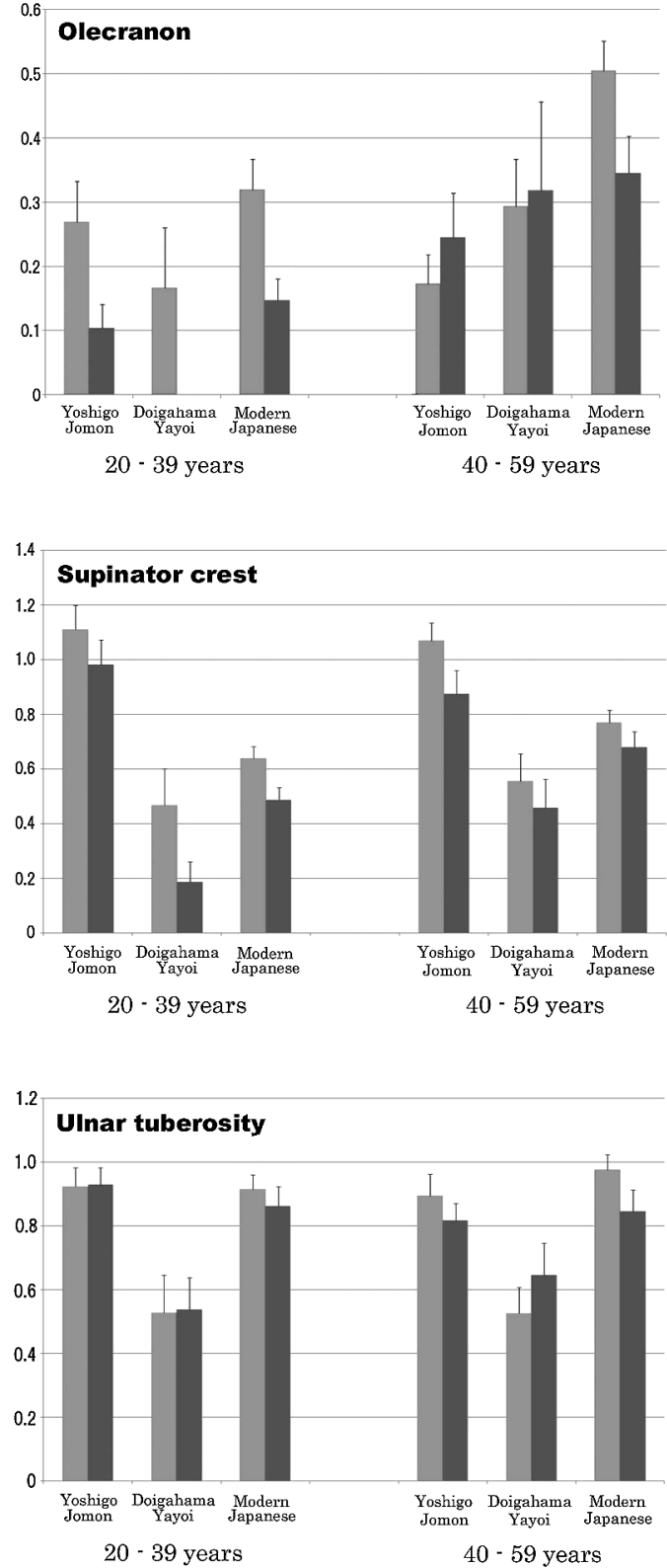

: Male $\quad$ Error bars show standard errors.

: Female

Figure 4. Bar charts of MSM score of the Jomon, Yayoi, and modern Japanese in each age class: (a) upper limbs; (b) lower limbs. 
(b)
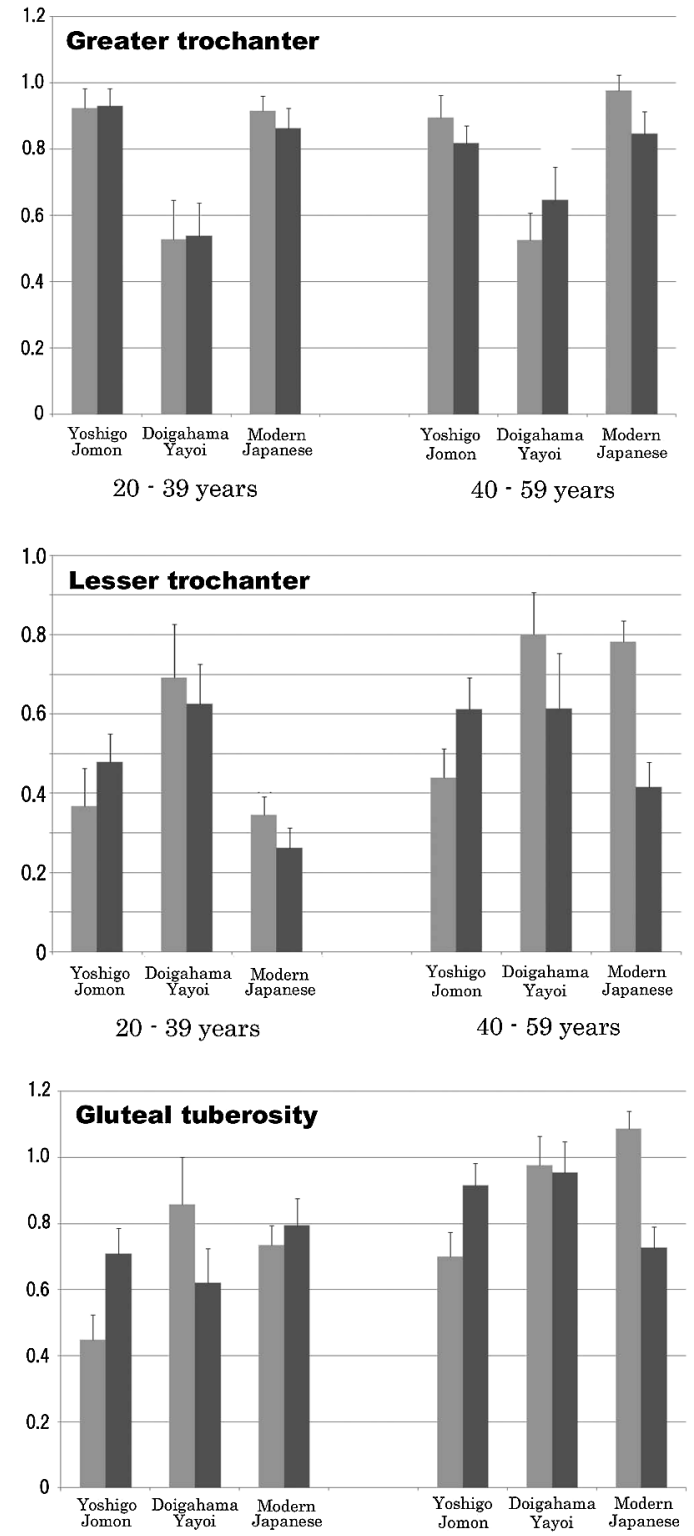

20 - 39 years

40 - 59 years

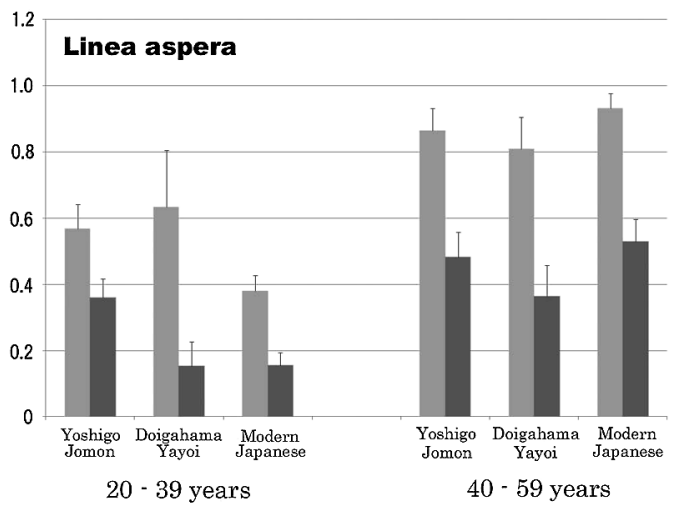

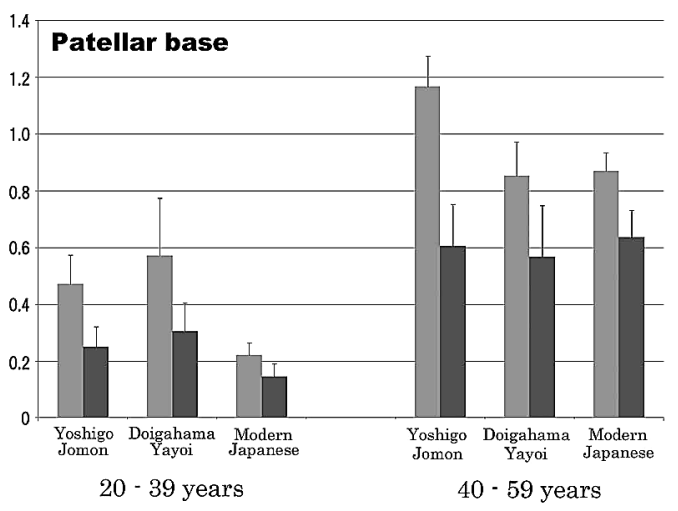
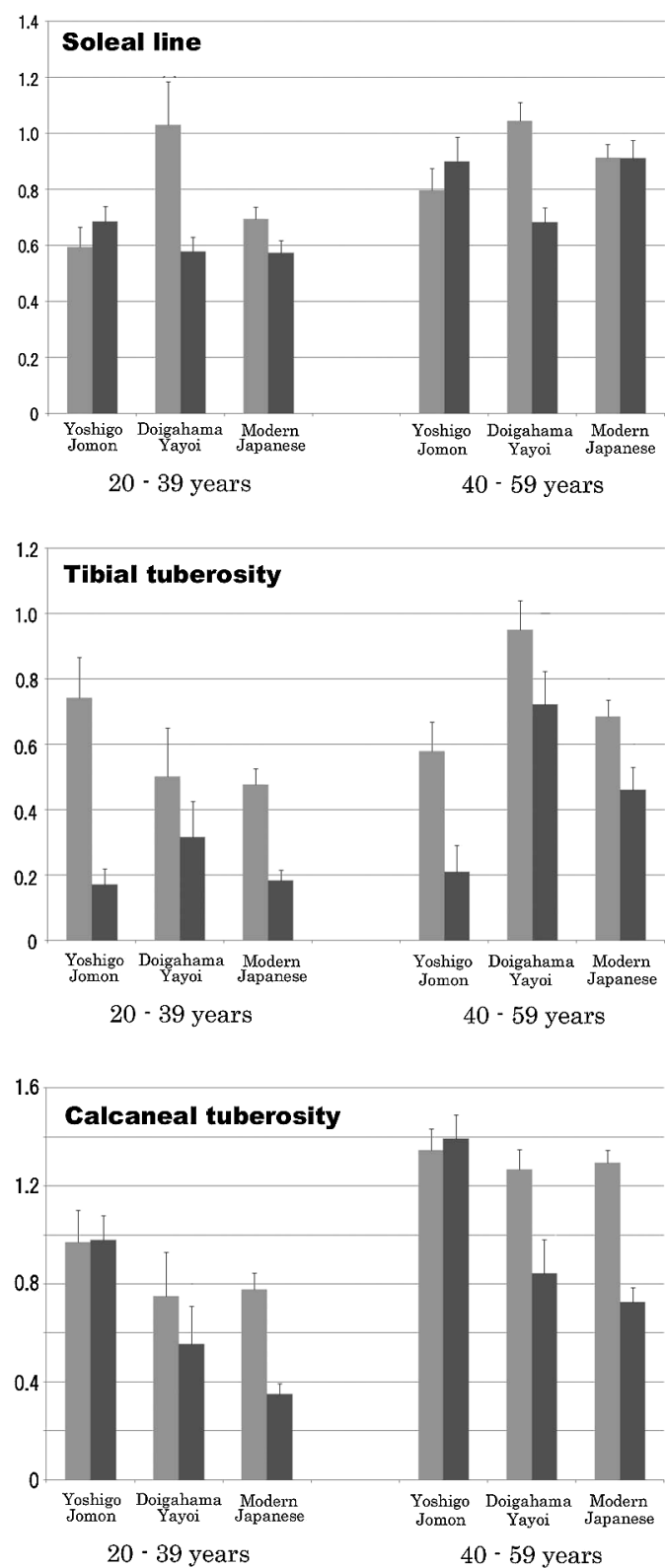

Figure 4. (continued) 

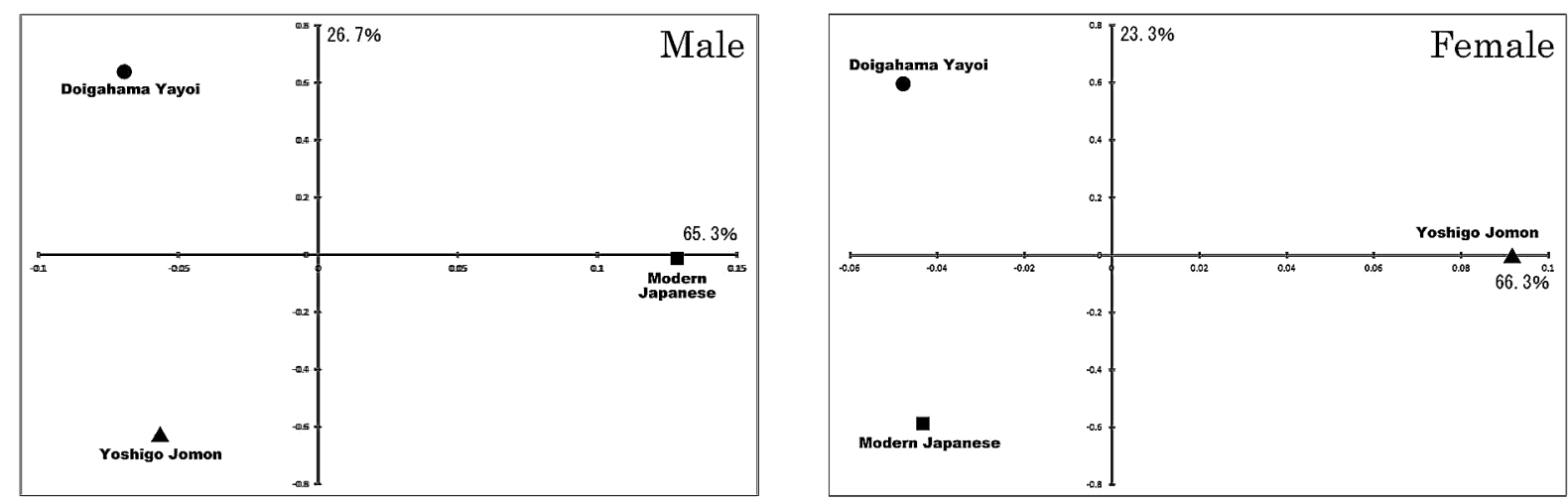

Younger adult (20-39 years)
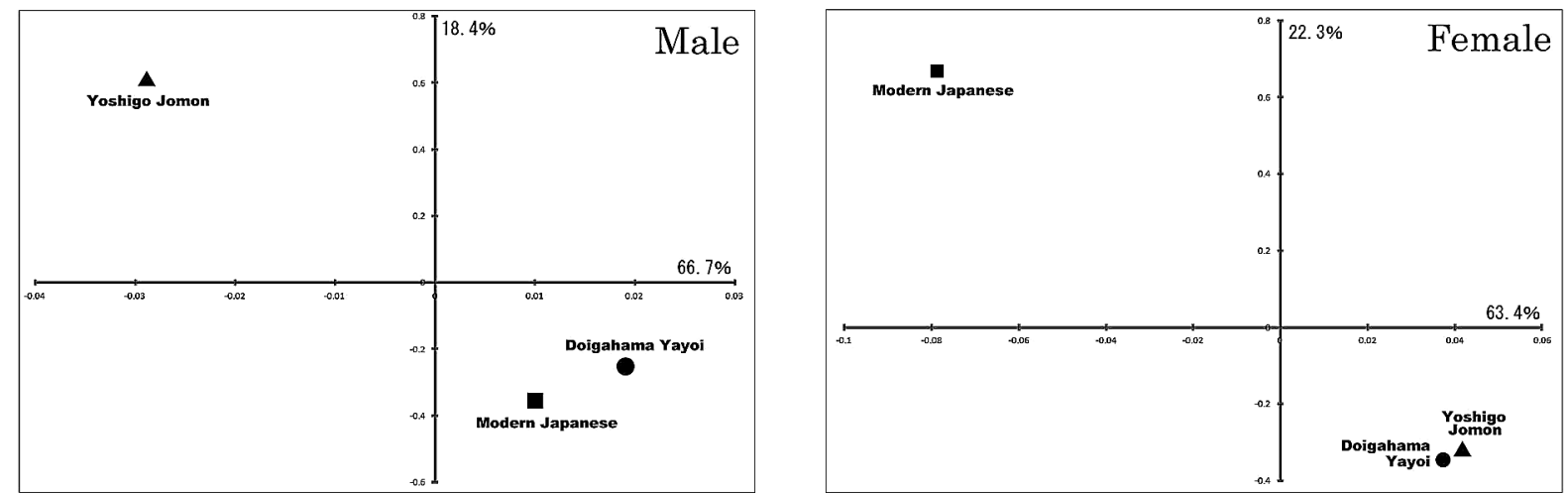

Older adult (40-59 years)
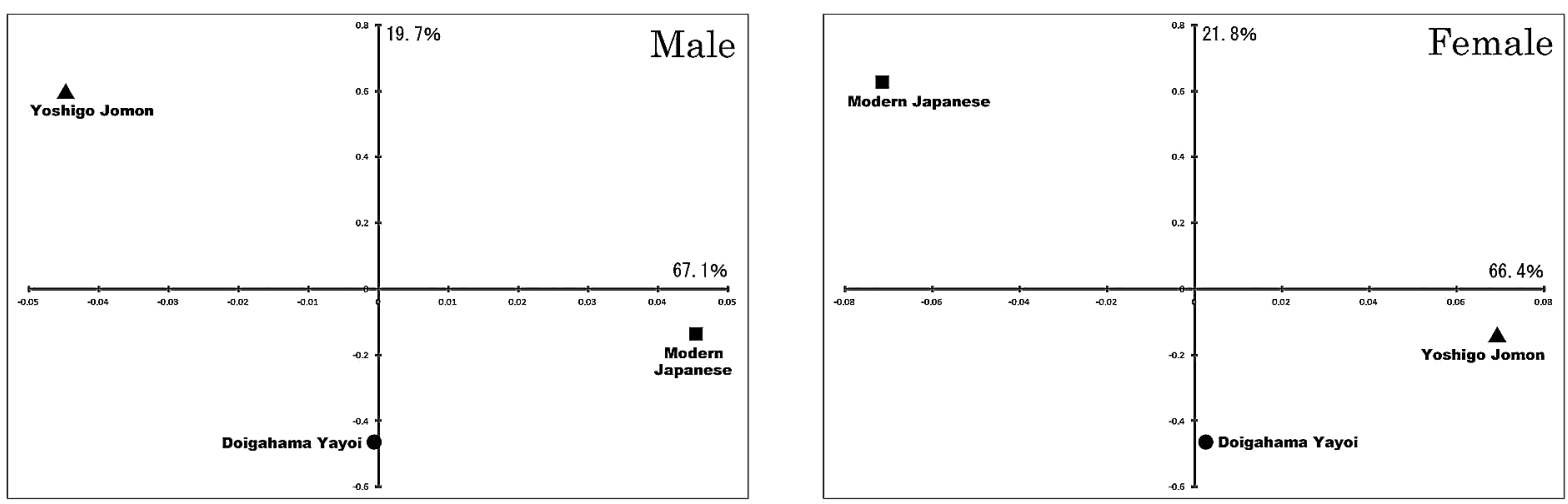

Mixed age groups (20-59 years)

Figure 5. Scatter diagrams of the Jomon, Yayoi, and modern Japanese based on principal component analysis. 
Table 6. Results of Mann-Whitney tests between younger and older adults in each group

\begin{tabular}{|c|c|c|c|c|c|c|c|c|}
\hline \multirow{2}{*}{ No. } & \multirow{2}{*}{ Element } & \multirow{2}{*}{ MSMs } & \multicolumn{2}{|c|}{ Yoshigo Jomon } & \multicolumn{2}{|c|}{ Doigahama Yayoi } & \multicolumn{2}{|c|}{ Modern Japanese } \\
\hline & & & Male & Female & Male & Female & Male & Female \\
\hline 1 & Humerus & GTC & ns & ns & ns & ns & $* *$ & ns \\
\hline 2 & Humerus & LTC & ns & ns & ns & ns & $* * *$ & ns \\
\hline 3 & Humerus & DT & ns & $\mathrm{ns}$ & $*$ & ns & $* * *$ & $* * *$ \\
\hline 4 & Radius & RT & ns & $\mathrm{ns}$ & ns & $*$ & $* * *$ & ns \\
\hline 5 & Ulna & $\mathrm{OL}$ & ns & $*$ & ns & $*$ & $* *$ & $* *$ \\
\hline 6 & Ulna & $\mathrm{SC}$ & ns & ns & ns & $*$ & ns & $*$ \\
\hline 7 & Ulna & UT & ns & $\mathrm{ns}$ & ns & $\mathrm{ns}$ & ns & ns \\
\hline 8 & Femur & GT & ns & ns & ns & ns & $* * *$ & $*$ \\
\hline 9 & Femur & LT & ns & ns & ns & ns & $* * *$ & $*$ \\
\hline 10 & Femur & GLT & $*$ & $*$ & ns & $* *$ & $* * *$ & ns \\
\hline 11 & Femur & LA & $* *$ & ns & ns & $*$ & $* * *$ & $* * *$ \\
\hline 12 & Patella & $\mathrm{PB}$ & $* * *$ & ns & ns & ns & $* * *$ & $* * *$ \\
\hline 13 & Tibia & SL & ns & ns & ns & $\mathrm{ns}$ & $* * *$ & $* * *$ \\
\hline 14 & Tibia & $\mathrm{TT}$ & $\mathrm{ns}$ & ns & $*$ & $*$ & $* *$ & $* * *$ \\
\hline 15 & Calcaneus & $\mathrm{CL}$ & $*$ & $*$ & $*$ & ns & $* * *$ & $* * *$ \\
\hline
\end{tabular}

Medicine, Chiba University), Mr. Masuyama S. (Educational Board of Tahara City), Dr. Nakahashi T. and Dr. Tanaka Y. (Graduate School of Social and Cultural Studies, Kyushu University), Dr. Iwanaga S. and Dr. Funahashi K. (Kyushu University Museum). In addition, the author also expresses gratitude to Dr. Hudson M. (Nishikyushu University) for proofreading, the editors, the associate editors of Anthropological Science, and the reviewers of this paper. This study was supported by a Grant-in-Aid for Scientific Research, MEXT (Ministry of Education, Culture, Sports, Science and Technology, Japan), Young Research B (Title: Life History of the Jomon People Reconstructed from Musculoskeletal Stress Markers, No. 22700847).

\section{References}

al-Oumaoui I., Jiménez-Brobeil S., and du Souich P. (2004) Markers of activity patterns in some populations of the Iberian Peninsula. International Journal of Osteoarchaeology, 14: 343-359.

Buikstra J. and Ubelaker D. (eds.) (1994) Standards for Data Collection from Human Skeletal Remains: Proceedings of a Seminar at The Field Museum of Natural History Organized by Jonathan Haas, Arkansas Archaeological Survey Research Series No. 44, Fayetteville, AS.

Cardoso A. and Henderson Y. (2010) Enthesopathy formation in the humerus: data from known age-at-death and known occupation skeletal collections. American Journal of Physical Anthropology, 141: 550-560.

Chapman M. (1997) Evidence for Spanish influence on activity induced musculoskeletal stress markers at Pecos Pueblo. International Journal of Osteoarchaeology, 7: 497-506.

Churchill E. and Morris G. (1998) Muscle marking morphology and labour intensity in prehistoric Khoisan foragers. International Journal of Osteoarchaeology, 8: 390-411.

Eshed V., Gopher A., Galili E., and Hershkovitz I. (2004) Musculoskeletal stress markers in Natufian hunter-gatherers and Neolithic farmers in the Levant: the upper limb. American Journal of Physical Anthropology, 123: 303-315.

Havelková P., Villotte S., Velemínský P., Poláček L., and Dobisíková M. (2011) Enthesopathies and activity patterns in the Early Medieval Great Moravian population: Evidence of division of labour. International Journal of Osteoarchaeology, 21: 487-504

Hawkey E. and Merbs F. (1995) Activity-induced musculoskeletal stress markers (MSM) and subsistence strategy changes among ancient Hudson Bay Eskimos. International Journal of Osteoarchaeology, 5: 324-338.

Lieverse R., Bazaliiskii I., Goriunova I., and Weber W. (2009) Upper limb musculoskeletal stress markers among middle Holocene foragers of Siberia's Cis-Baikal region. American Journal of Physical Anthropology, 138: 458-472.

Lieverse R., Bazaliiskii I., Goriunova I., and Weber W. (2013) Lower limb activity in the Cis-Baikal: entheseal changes among middle Holocene Siberian foragers. American Journal of Physical Anthropology, 150: 4210432.

Lovejoy C. (1985) Dental wear in the Libben population: its functional pattern and role in the determination of adult skeletal age at death. American Journal of Physical Anthropology, 68: $47-56$.

Milella M., Belcastro G., Zollikofer P., and Mariotti V. (2012) The effect of age, sex, and physical activity on entheseal morphology in a contemporary Italian skeletal collection. American Journal of Physical Anthropology, 148: 379-388.

Molnar P. (2006) Tracing prehistoric activities: musculoskeletal stress marker analysis of a Stone-Age population on the Island of Gotland in the Baltic Sea. American Journal of Physical Anthropology, 129: 12-23.

Molnar P. (2010) Patterns of physical activity and material culture on Gotland, Sweden, during the Middle Neolithic. International Journal of Osteoarchaeology, 20: 1-14.

Molnar P., Ahlstrom P., and Leden I. (2011) Osteoarthritis and activity - an analysis of the relationship between eburnation, musculoskeletal stress markers (MSM) and age in two Neolithic hunter-gatherer populations from Gotland, Sweden. International Journal of Osteoarchaeology, 21: 283-291.

Niinimäki S. (2011) What do muscle marker ruggedness scores actually tell us? International Journal of Osteoarchaeology, 21: $292-299$.

Okazaki K. (2007) Habitual behaviors in the Jomon people, based on the analysis of the external cross sections of juvenile limb bones. Anthropological Science (Japanese Series), 115: 109125 (in Japanese).

Peterson J. (1998) The Natufian hunting conundrum: spears, atlatls, or bows? musculoskeletal and armature evidence. International Journal of Osteoarchaeology, 8: 378-389.

Robb J. (1998) The interpretation of skeletal muscle sites: a statistical approach. International Journal of Osteoarchaeology, 8: 363-377.

Schrader A. (2012) Activity patterns in New Kingdom Nubia: an examination of entheseal remodeling and osteoarthritis at Tombos. American Journal of Physical Anthropology, 149: $60-70$. 
Steen L. and Lane W. (1998) Evaluation of habitual activities among two Alaskan Eskimo populations based on musculoskeletal stress markers. International Journal of Osteoarchaeology, 8: 341-353.

Stefanović S. and Porčić M. (2013) Between-group differences in the patterning of musculo-skeletal stress markers: avoiding confounding factors by focusing on qualitative aspects of physical activity. International Journal of Osteoarchaeology, 23: 94-105.

Weiss E. (2003) Understanding muscle markers: aggregation and construct validity. American Journal of Physical Anthropology, 121: 230-240
Weiss E. (2004) Understanding muscle markers: lower limbs American Journal of Physical Anthropology, 125: 232-238.

Weiss E. (2007) Muscle markers revisited: activity pattern reconstruction with controls in a central California Amerind population. American Journal of Physical Anthropology, 133: 931-940.

Wescott D. and Child S. (2009) Evidence of reduced mobility in a Missouri Woodland Period adolescent male. American Journal of Physical Anthropology, 138 (Supplement 48): 270.

Wilczak C. (1998) Consideration of sexual dimorphism, age, and asymmetry in quantitative measurements of muscle insertion sites. International Journal of Osteoarchaeology, 8: 311-325. 